\title{
LEVEL II SCOUR ANALYSIS FOR BRIDGE 33 (WWINTH00300033) on TOWN HIGHWAY 30, crossing MILL BROOK, WEST WINDSOR, VERMONT
}

Open-File Report 98-256

Prepared in cooperation with

VERMONT AGENCY OF TRANSPORTATION

and

FEDERAL HIGHWAY ADMINISTRATION

U.S. Department of the Interior

U.S. Geological Survey

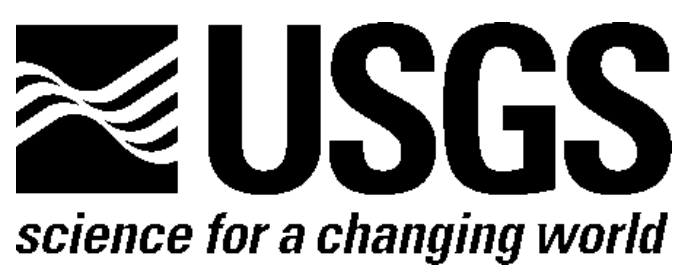




\section{LEVEL II SCOUR ANALYSIS FOR BRIDGE 33 (WWINTH00300033) on TOWN HIGHWAY 30, crossing MILL BROOK, WEST WINDSOR, VERMONT \\ By EMILY C. WILD and ROBERT H. FLYNN}

U.S. Geological Survey Open-File Report 98-256

Prepared in cooperation with

VERMONT AGENCY OF TRANSPORTATION

and

FEDERAL HIGHWAY ADMINISTRATION 


\title{
U.S. DEPARTMENT OF THE INTERIOR BRUCE BABBITT, Secretary
}

\author{
U.S. GEOLOGICAL SURVEY
}

Thomas Casadevall, Acting Director

For additional information write to:

District Chief

U.S. Geological Survey 361 Commerce Way

Pembroke, NH 03275-3718
Copies of this report may be purchased from:

U.S. Geological Survey

Branch of Information Services

Open-File Reports Unit

Box 25286

Denver, CO 80225-0286 


\section{CONTENTS}

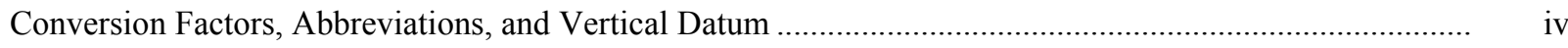

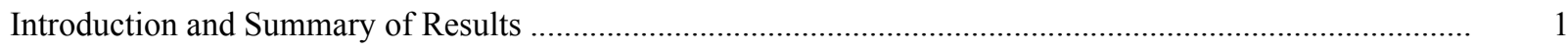

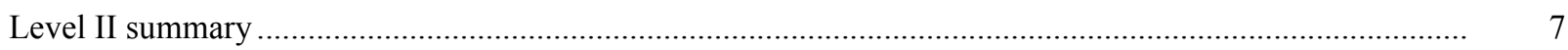

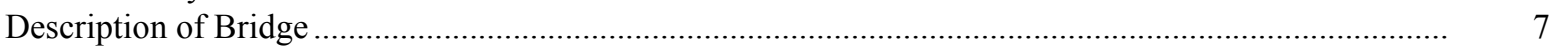

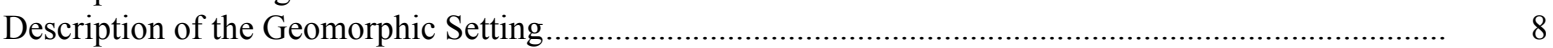

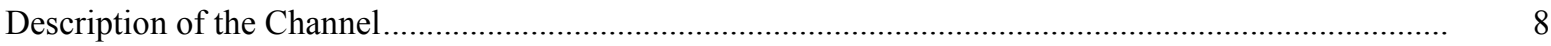

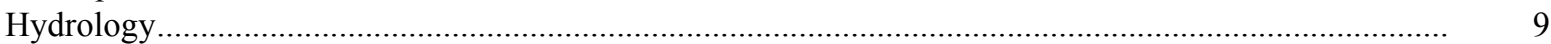

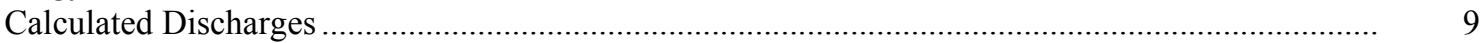

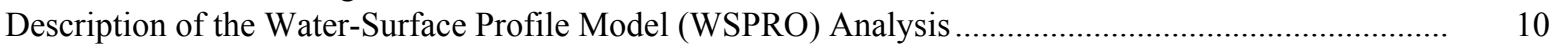

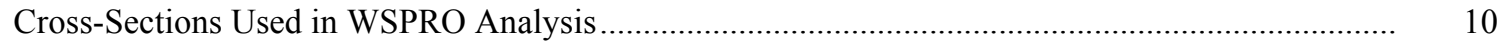

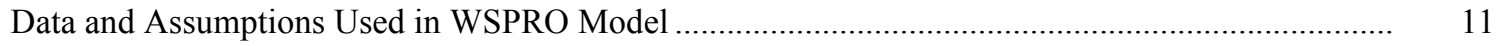

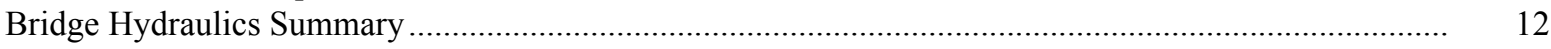

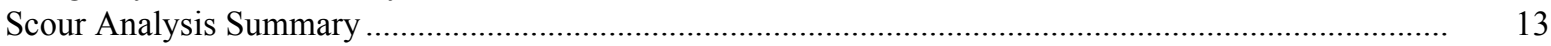

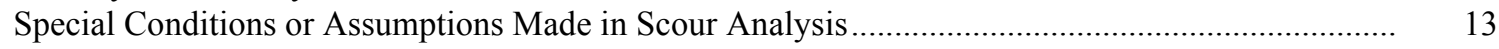

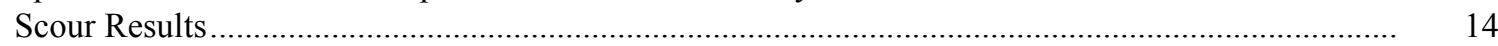

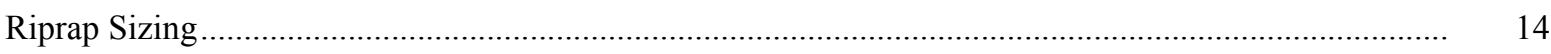

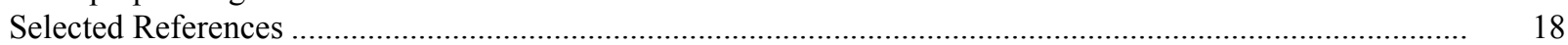

Appendices:

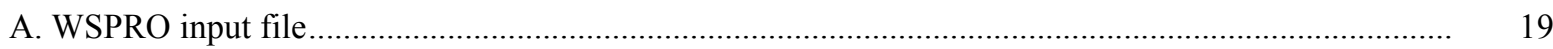

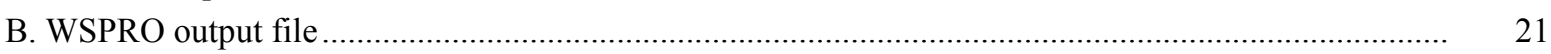

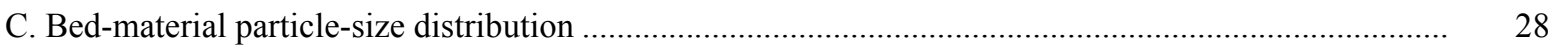

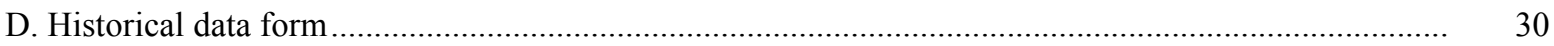

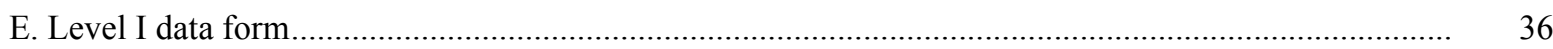

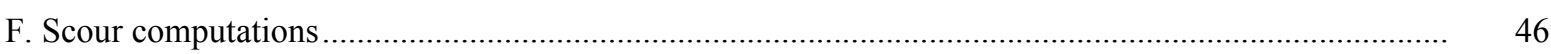

\section{FIGURES}

1. Map showing location of study area on two USGS 1:62,500 scale map

2. Map showing location of study area on Vermont Agency of Transportation town

highway map

3. Structure WWINTH00300033 viewed from upstream (June 5, 1996)

4. Downstream channel viewed from structure WWINTH00300033 (June 5, 1996).

5. Upstream channel viewed from structure WWINTH00300033 (June 5, 1996).

6. Structure WWINTH00300033 viewed from downstream (June 5, 1996).

7. Water-surface profiles for the 100- and 500-year discharges at structure

WWINTH00300033 on Town Highway 30, crossing Mill Brook,

West Windsor, Vermont. 1 ( 36 


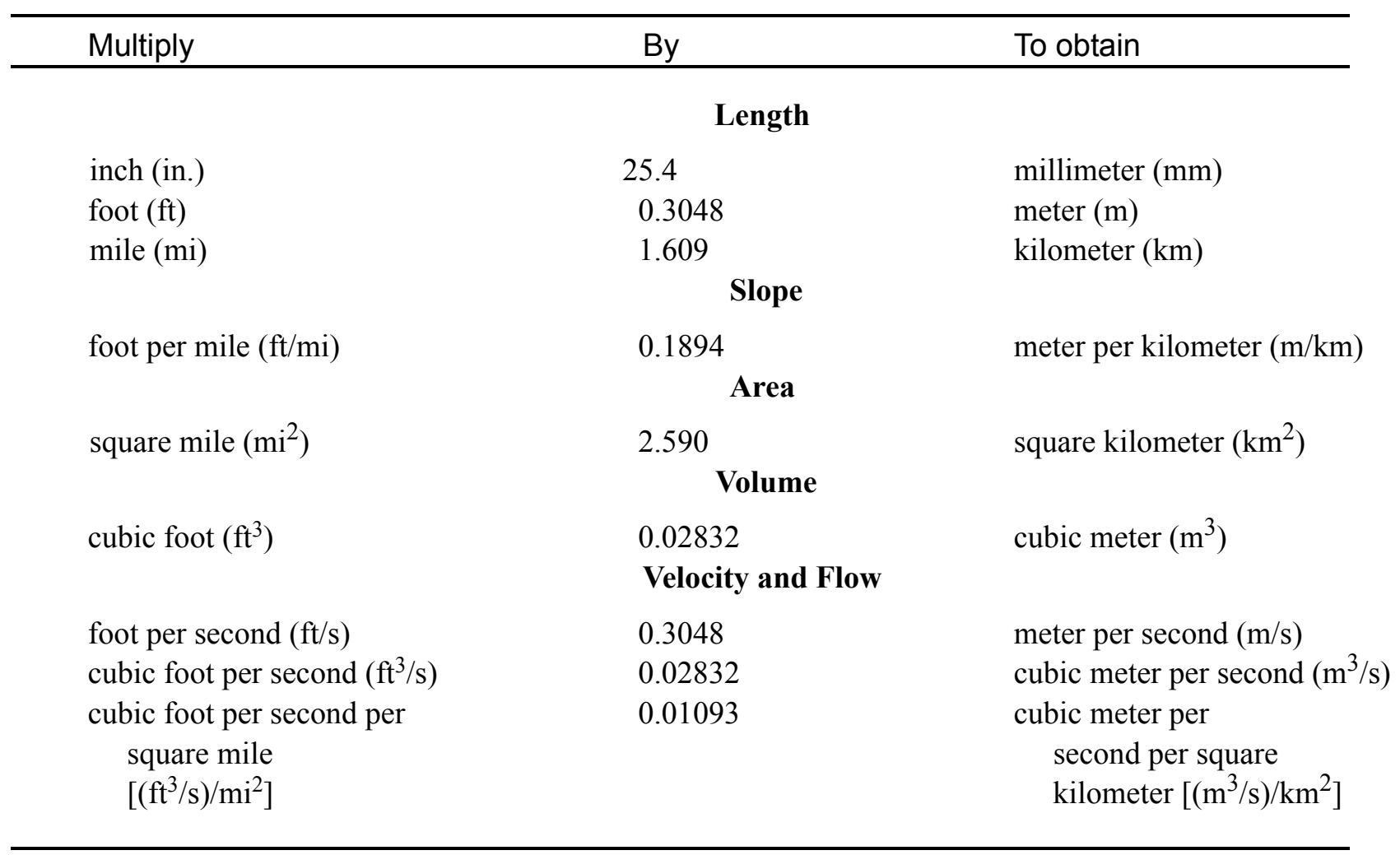

\section{OTHER ABBREVIATIONS}

\begin{tabular}{|c|c|c|c|}
\hline $\mathrm{BF}$ & bank full & LWW & left wingwall \\
\hline $\mathrm{cfs}$ & cubic feet per second & Max & maximum \\
\hline $\mathrm{D}_{50}$ & median diameter of bed material & $\mathrm{MC}$ & main channel \\
\hline DS & downstream & RAB & right abutment \\
\hline elev. & elevation & RABUT & face of right abutment \\
\hline $\mathrm{f} / \mathrm{p}$ & flood plain & $\mathrm{RB}$ & right bank \\
\hline $\mathrm{ft}^{2}$ & square feet & ROB & right overbank \\
\hline $\mathrm{ft} / \mathrm{ft}$ & feet per foot & RWW & right wingwall \\
\hline FEMA & Federal Emergency Management Agency & $\mathrm{TH}$ & town highway \\
\hline FHWA & Federal Highway Administration & UB & under bridge \\
\hline JCT & junction & US & upstream \\
\hline LAB & left abutment & USGS & United States Geological Survey \\
\hline LABUT & face of left abutment & VTAOT & Vermont Agency of Transportation \\
\hline LB & left bank & WSPRO & water-surface profile model \\
\hline LOB & left overbank & $\mathrm{yr}$ & year \\
\hline
\end{tabular}

In this report, the words "right" and "left" refer to directions that would be reported by an observer facing downstream.

Sea level: In this report, "sea level" refers to the National Geodetic Vertical Datum of 1929-- a geodetic datum derived from a general adjustment of the first-order level nets of the United States and Canada, formerly called Sea Level Datum of 1929.

In the appendices, the above abbreviations may be combined. For example, USLB would represent upstream left bank. 


\title{
LEVEL II SCOUR ANALYSIS FOR BRIDGE 33 (WWINTH00300033) ON TOWN HIGHWAY 30, CROSSING MILL BROOK, WEST WINDSOR, VERMONT
}

\author{
By Emily C. Wild and Robert H. Flynn
}

\section{INTRODUCTION AND SUMMARY OF RESULTS}

This report provides the results of a detailed Level II analysis of scour potential at structure WWINTH00300033 on Town Highway 30 crossing Mill Brook, West Windsor, Vermont (Figures 1-8). A Level II study is a basic engineering analysis of the site, including a quantitative analysis of stream stability and scour (FHWA, 1993). Results of a Level I scour investigation also are included in appendix $\mathrm{E}$ of this report. A Level I investigation provides a qualitative geomorphic characterization of the study site. Information on the bridge, gleaned from Vermont Agency of Transportation (VTAOT) files, was compiled prior to conducting Level I and Level II analyses and is found in appendix D.

The site is in the New England Upland section of the New England physiographic province in east-central Vermont. The $24.9-\mathrm{mi}^{2}$ drainage area is in a predominantly rural and forested basin. In the vicinity of the study site, the surface cover is pasture upstream of the bridge while the immediate banks have dense woody vegetation. Downstream of the bridge is forested.

In the study area, Mill Brook has an incised, sinuous channel with a slope of approximately $0.004 \mathrm{ft} / \mathrm{ft}$, an average channel top width of $58 \mathrm{ft}$ and an average bank height of $5 \mathrm{ft}$. The channel bed material ranges from sand to boulder with a median grain size $\left(D_{50}\right)$ of 65.7 $\mathrm{mm}(0.215 \mathrm{ft})$. The geomorphic assessment at the time of the Level I and Level II site visit on June 5, 1996, indicated that the reach was stable.

The Town Highway 30 crossing of the Mill Brook is a 46-ft-long, one-lane covered bridge consisting of a 40-foot wood-beam span (Vermont Agency of Transportation, written communication, March 23, 1995). The opening length of the structure parallel to the bridge face is $36.3 \mathrm{ft}$. The bridge is supported by vertical, concrete capped laid-up stone abutments with wingwalls. The channel is skewed approximately 10 degrees to the opening while the opening-skew-to-roadway is zero degrees.

The only scour protection measure at the site was type- 2 stone fill (less than 36 inches diameter) along the upstream right bank, the upstream right wingwall, the right abutment and the downstream left wingwall. Additional details describing conditions at the site are included in the Level II Summary and appendices D and $\mathrm{E}$. 
Scour depths and recommended rock rip-rap sizes were computed using the general guidelines described in Hydraulic Engineering Circular 18 (Richardson and Davis, 1995) for the 100- and 500-year discharges. In addition, the incipient roadway-overtopping discharge was analyzed since it had the potential of being the worst-case scour scenario. Total scour at a highway crossing is comprised of three components: 1) long-term streambed degradation; 2) contraction scour (due to accelerated flow caused by a reduction in flow area at a bridge) and; 3 ) local scour (caused by accelerated flow around piers and abutments). Total scour is the sum of the three components. Equations are available to compute depths for contraction and local scour and a summary of the results of these computations follows.

Contraction scour for all modelled flows ranged from 0.0 to $0.1 \mathrm{ft}$. The worst-case contraction scour occurred at the 500-year discharge. Abutment scour ranged from 6.0 to $16.0 \mathrm{ft}$. The worst-case abutment scour occurred at the 500-year discharge. Additional information on scour depths and depths to armoring are included in the section titled "Scour Results". Scoured-streambed elevations, based on the calculated scour depths, are presented in tables 1 and 2. A cross-section of the scour computed at the bridge is presented in figure 8. Scour depths were calculated assuming an infinite depth of erosive material and a homogeneous particle-size distribution.

Usually, computed scour depths are evaluated in combination with other information including (but not limited to) historical performance during flood events, the geomorphic stability assessment, existing scour protection measures, and the results of the hydraulic analyses. Therefore, scour depths adopted by VTAOT may differ from the computed values documented herein. 


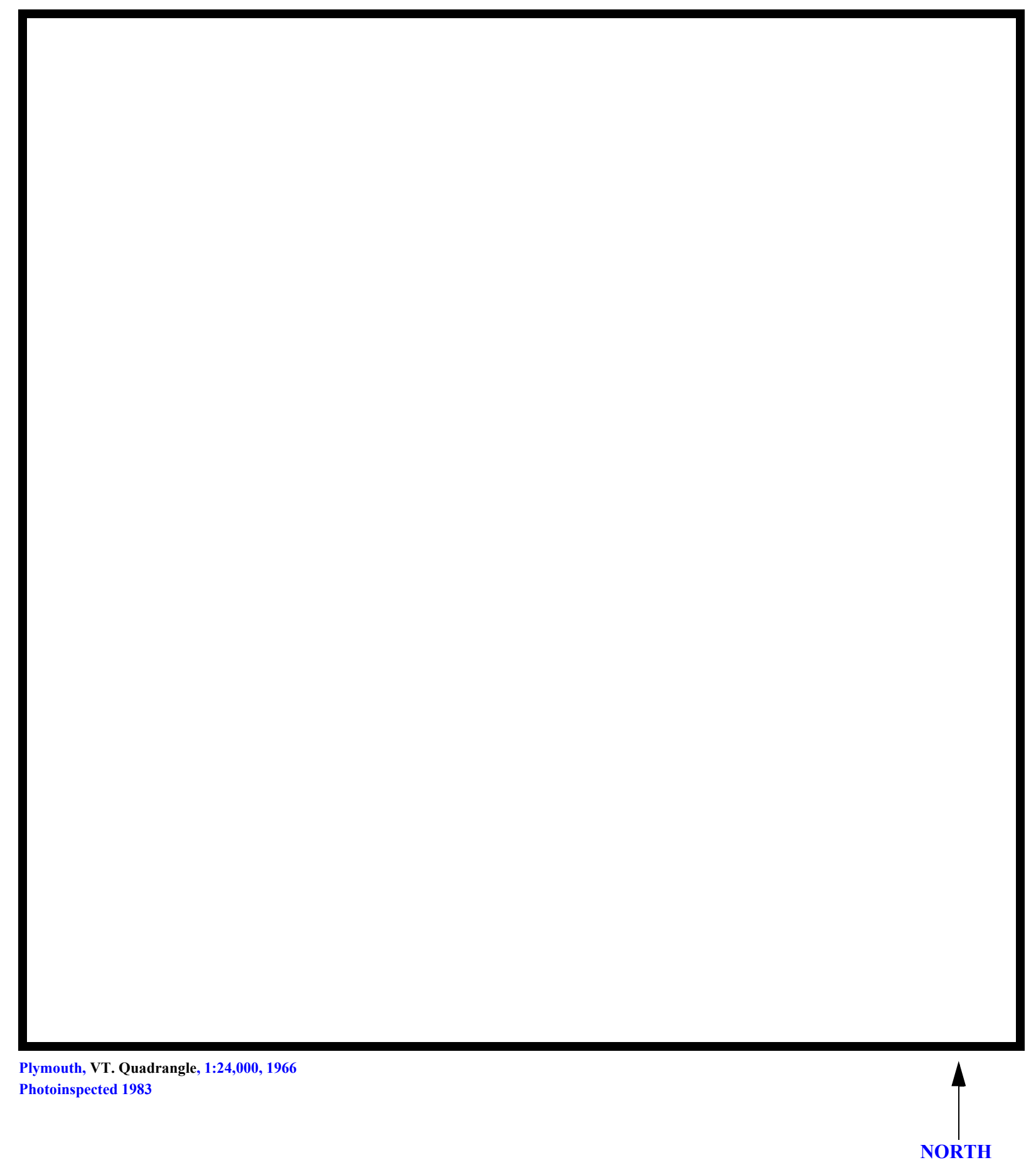

Figure 1. Location of study area on USGS 1:24,000 scale map. 
Figure 2. Location of study area on Vermont Agency of Transportation town highway map. 

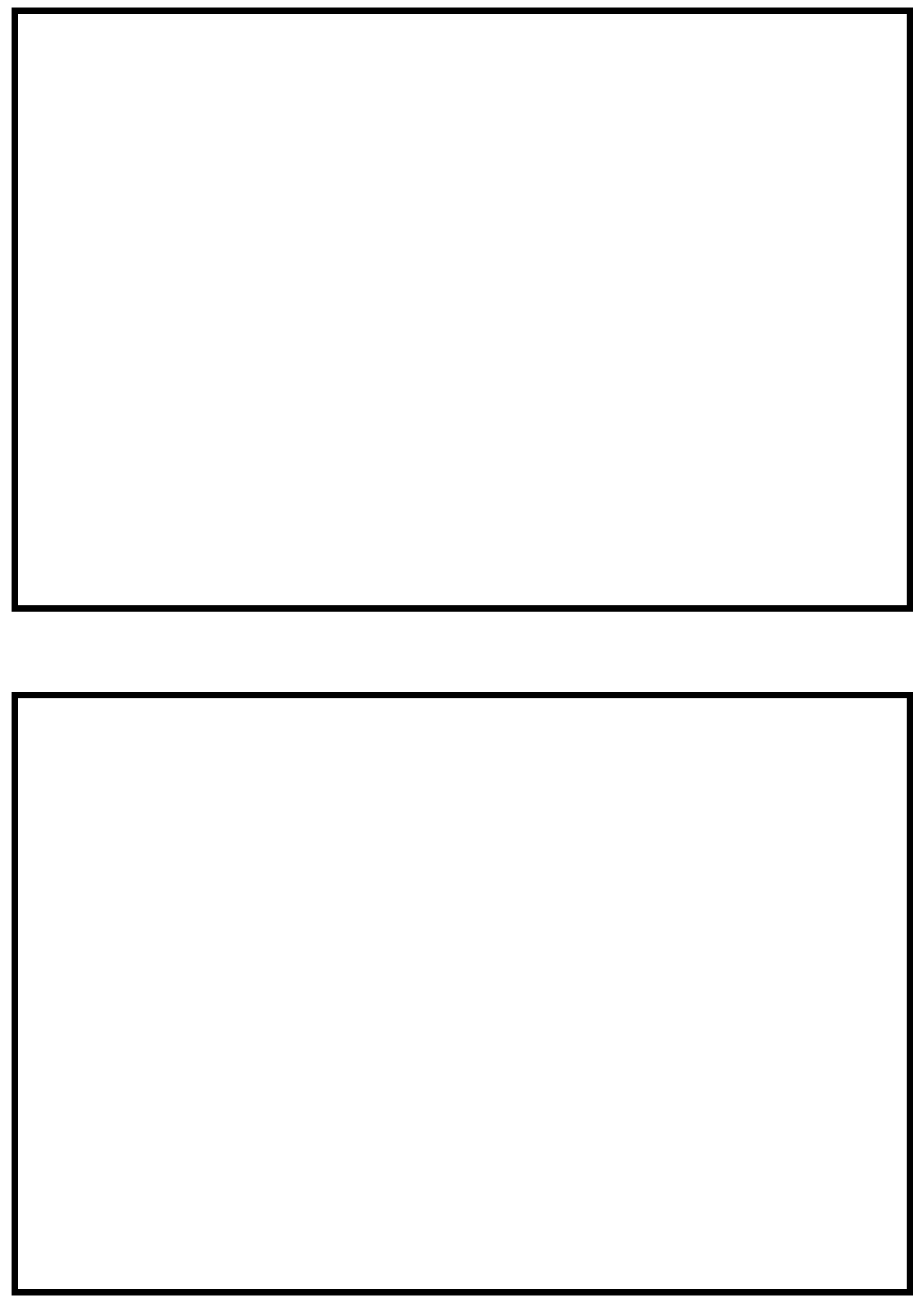

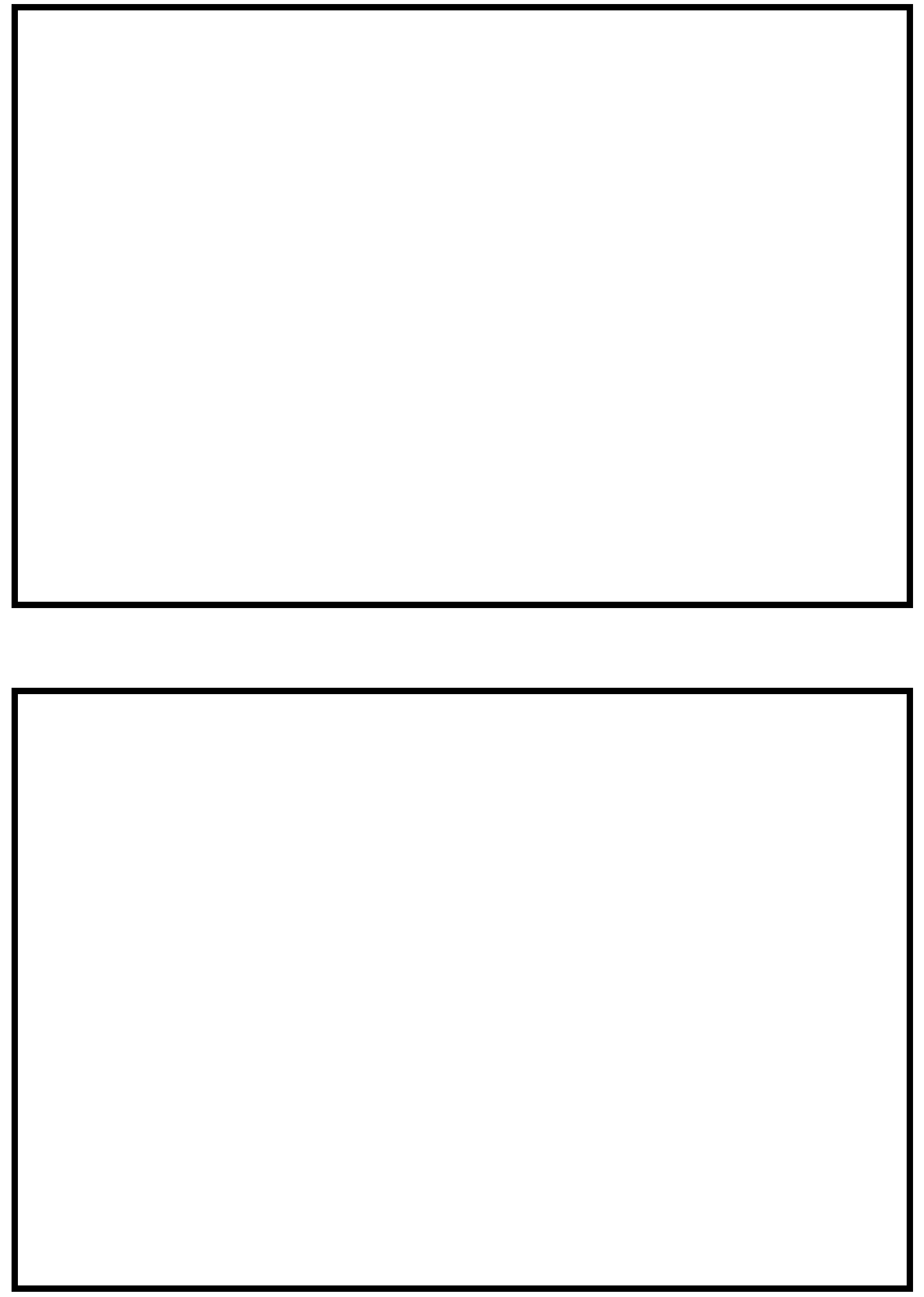


\section{LEVEL II SUMMARY}

\begin{tabular}{llllll} 
Structure Number & WWINTH00300033 & & \multicolumn{2}{c}{ Mill Brook } & \\
Stream & & & \\
County & Windsor & Road & TH30 & District & 4
\end{tabular}

\section{Description of Bridge}

Bridge length $\frac{46}{4} \quad \boldsymbol{f t}$ Bridge width $\frac{12.3}{f t}$ Max span length $\frac{40}{f t}$ Alignment of bridge to road (on curve or straight) Vertical, laid-up stone Abutment type

Stone fill on abutment? Yes

\section{Embankment type} Straight

nomsuintion af atom n fill

Dato af insnortion Type-2, along the upstream right wingwall, the right abutment and the Sloping downstream left wingwall.

Abutments and wingwalls are laid-up stone with concrete caps.

\section{Y} 10

Is bridge skewed to flood flow according to N_ ' survey? Angle A mild channel bend is present within the upstream reach and within the downstream reach. $6 / 5 / 96$

Debris accumulation on bridge at time of Level I or Level II site visit:

\begin{tabular}{|c|c|c|c|}
\hline & $\begin{array}{l}\text { Date of insnortion } \\
0\end{array}$ & $\begin{array}{l}\text { Percent of alsmunt } \\
\text { blocked inortzontatly }\end{array}$ & $\begin{array}{l}\text { Percent of } 6 / 5 / 960 \text { el } \\
\text { blocked verticatty }\end{array}$ \\
\hline Level I & 0 & 0 & Moder \\
\hline evel II & ate. & & \\
\hline
\end{tabular}

\section{Potential for debris}

None, 6/5/96.

Dosriho anv, fonturos noar ar at tho hridoo that mav affort flow, (includo ahsorvation dato) 


\section{Description of the Geomorphic Setting}

General topography The channel is located within a narrow flood plain with steep valley walls on both sides.

Geomorphic conditions at bridge site: downstream (DS), upstream (US)

Date of inspection $\quad 6 / 5 / 96$

DS left: $\quad$ Moderately sloped overbank

DS right: $\quad$ Moderately sloped overbank

US left: $\quad$ Moderately sloped overbank

US right: $\quad$ Moderately sloped overbank

\section{Description of the Channel}

$\begin{array}{llll}\text { Average top width } & 58 & \text { Average depth } & 5 \\ & \text { Sand / Cobbles } & \text { Sand/Cobbles }\end{array}$

Predominant bed material

Bank material Sinuous with semi-

alluvial channel boundaries and a narrow flood plain.

$6 / 5 / 96$

Vegetative co 1 Forest.

DS left: $\quad$ Forest.

DS right: $\quad$ Pasture with a few trees.

US left: $\quad$ Pasture with a few trees.

US right: $\quad$ No

Do banks appear stable? The channel banks,were noted as laterally unstable during the June 5 , date of observation.

None, 6/5/96.

Describe any obstructions in channel and date of observation. 


\section{Hydrology}

Drainage area $\quad 24.9 \boldsymbol{m i}^{2}$

Percentage of drainage area in physiographic provinces: (approximate)

Physiographic province/section New England/New England Upland
Percent of drainage area 100

Is drainage area considered rural or urban? — Rural _ Describe any significant urbanization:

Is there a USGS gage on the stream of interest?

No

USGS gage description

USGS gage number

Gage drainage area $\mathrm{mi}^{2}$

Is there a lake/p

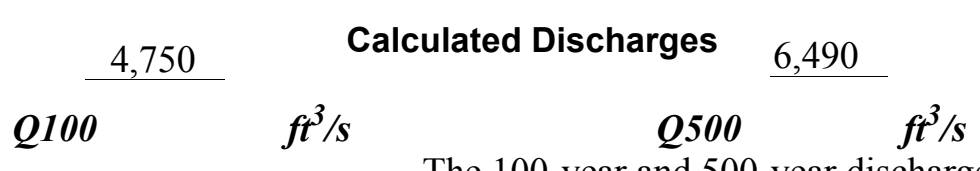

The 100-year and 500-year discharges are the

median values taken from empirical flood frequency curves (Benson, 1962; Johnson and Tasker, 1974; FHWA, 1983; Potter, 1957a\&b; Talbot, 1887). Each curve was extended graphically to the 500-year event. 


\section{Description of the Water-Surface Profile Model (WSPRO) Analysis}

Datum for WSPRO analysis (USGS survey, sea level, VTAOT plans)

USGS survey

Datum tie between USGS survey and VTAOT plans

None.

Description of reference marks used to determine USGS datum. $\quad$ RM1 is a chiseled X on top of the downstream end of the left abutment (elev. $502.85 \mathrm{ft}$, arbitrary survey datum). RM2 is a nail in tree, three feet from the tree base, located approximately 50 feet downstream of the bridge on the right bank (elev. $502.02 \mathrm{ft}$, arbitrary survey datum).

\section{Cross-Sections Used in WSPRO Analysis}

\begin{tabular}{ccll}
\hline${ }^{1}$ Cross-section & $\begin{array}{c}\text { Section } \\
\text { Reference } \\
\text { Distance } \\
\text { (SRD) in feet }\end{array}$ & $\begin{array}{c}{ }^{2} \text { Cross-section } \\
\text { development }\end{array}$ & \multicolumn{1}{c}{ Comments } \\
\hline EXITX & -49 & 1 & $\begin{array}{l}\text { Exit section } \\
\text { Downstream Full-valley } \\
\text { section (Templated from } \\
\text { EXITX) }\end{array}$ \\
BRIDG & 0 & 2 & $\begin{array}{l}\text { Bridge section } \\
\text { Road Grade section }\end{array}$ \\
RDWAY & 0 & 1 & $\begin{array}{l}\text { Modelled Approach sec- } \\
\text { tion (Templated from } \\
\text { APTEM) } \\
\text { APPRO }\end{array}$ \\
& 8 & 1 & $\begin{array}{l}\text { Approach section as sur- } \\
\text { veyed (Used as a tem- } \\
\text { plate) }\end{array}$ \\
\hline
\end{tabular}

${ }^{1}$ For location of cross-sections see plan-view sketch included with Level I field form, Appendix E. For more detail on how cross-sections were developed see WSPRO input file. 


\section{Data and Assumptions Used in WSPRO Model}

Hydraulic analyses of the reach were done by use of the Federal Highway Administration's WSPRO step-backwater computer program (Shearman and others, 1986, and Shearman, 1990). The analyses reported herein reflect conditions existing at the site at the time of the study. Furthermore, in the development of the model it was necessary to assume no accumulation of debris or ice at the site. Results of the hydraulic model are presented in the Bridge Hydraulic Summary, appendix B, and figure 7.

Channel roughness factors (Manning's " $n$ ") used in the hydraulic model were estimated using field inspections at each cross section following the general guidelines described by Arcement and Schneider (1989). Final adjustments to the values were made during the modelling of the reach. Channel " $\mathrm{n}$ " values for the reach ranged from 0.055 to 0.060 , and overbank " $n$ " values ranged from 0.045 to 0.065 .

Normal depth at the exit section (EXITX) was assumed as the starting water surface. This depth was computed by use of the slope-conveyance method outlined in the user's manual for WSPRO (Shearman, 1990). The slope used was $0.0042 \mathrm{ft} / \mathrm{ft}$, which was estimated from the 100-year discharge water-surface profile slope downstream of the bridge in the Flood Insurance Study for West Windsor, VT (Federal Emergency Management Agency, 1981).

The surveyed approach section (APTEM) was moved along the approach channel slope $(0.0048 \mathrm{ft} / \mathrm{ft})$ to establish the modelled approach section (APPRO), one bridge length upstream of the upstream face as recommended by Shearman and others (1986). This location also provides a consistent method for determining scour variables. 


\section{Bridge Hydraulics Summary}

\begin{tabular}{lll} 
Average bridge embankment elevation & 506.0 \\
\cline { 3 - 3 } Average low steel elevation & 503.8 & $\boldsymbol{f t}$
\end{tabular}

100-year discharge $\quad 4,750 \quad \mathrm{ft}^{3} / \mathrm{s}$

Water-surface elevation in bridge opening $\quad 503.8 \quad f t$

Road overtopping? ___ Y Discharge over road _ـ 1,729 $\mathrm{ft}^{3} / \mathrm{s}$

\begin{tabular}{lll} 
Area of flow in bridge opening & $354 \quad \mathrm{ft}^{2}$ \\
\cline { 2 - 3 } Average velocity in bridge opening & 8.5 & $\mathrm{ft} / \mathrm{s}$
\end{tabular}

$\begin{array}{llll}\text { Maximum WSPRO tube velocity at bridge } & 10.0 \quad \mathrm{tt} / \mathrm{s}\end{array}$

Water-surface elevation at Approach section with bridge 505.4

Water-surface elevation at Approach section without bridge $\quad 503.2$

Amount of backwater caused by bridge

$2.2 \quad \boldsymbol{t}$

500-year discharge $\quad 6,490 \quad \mathrm{ft}^{3} / \mathrm{s}$

Water-surface elevation in bridge opening $\quad 503.8 \mathrm{ft}$

Road overtopping? ___ Y Discharge over road _ $\quad 3,220 \quad \boldsymbol{f t}^{3} / \mathbf{s}$

Area of flow in bridge opening $\quad 354 \quad \mathrm{ft}^{2}$

Average velocity in bridge opening $\quad 9.5 \mathrm{ft} / \mathrm{s}$

Maximum WSPRO tube velocity at bridge 11.3 , /s

Water-surface elevation at Approach section with bridge 506.2

Water-surface elevation at Approach section without bridge $\quad 504.2$

Amount of backwater caused by bridge $\quad 2.0$.t

Incipient overtopping discharge $\quad 2,250 \quad \mathrm{ft}^{3} / \mathrm{s}$

Water-surface elevation in bridge opening $\quad 500.9$ t

Area of flow in bridge opening $\quad 252 \quad \mathrm{ft}^{2}$

Average velocity in bridge opening $\quad 8.9 \quad \mathrm{ft} / \mathrm{s}$

Maximum WSPRO tube velocity at bridge $11.0 \mathrm{ft} / \mathrm{s}$

Water-surface elevation at Approach section with bridge

Water-surface elevation at Approach section without bridge

502.5

Amount of backwater caused by bridge $\quad 1.1$ it 


\section{Scour Analysis Summary}

\section{Special Conditions or Assumptions Made in Scour Analysis}

Scour depths were computed using the general guidelines described in Hydraulic Engineering Circular 18 (Richardson and Davis, 1995). Scour depths were calculated assuming an infinite depth of erosive material and a homogeneous particle-size distribution. The results of the scour analyses for the 100- and 500-year discharges are presented in tables 1 and 2 and the scour depths are shown graphically in figure 8 .

Contraction scour for the incipient roadway-overtopping discharge was computed by use of the Laursen clear-water contraction scour equation (Richardson and Davis, 1995, p. 32, equation 20). At this site, the 100-year discharge resulted in unsubmerged orifice flow, and the 500-year discharge resulted in submerged orifice flow. Contraction scour at bridges with orifice flow is best estimated by use of the Chang pressure-flow scour equation (oral communication, J. Sterling Jones, October 4, 1996). Thus, contraction scour for the discharges resulting in orifice flow was computed by use of the Chang equation (Richardson and Davis, 1995, p. 145-146). The streambed armoring depths computed suggest that armoring will not limit the depth of contraction scour.

For comparison, contraction scour for the discharges resulting in orifice flow was computed by use of the Laursen clear-water contraction scour equation and the Umbrell pressure-flow equation (Richardson and Davis, 1995, p. 144). For those discharges resulting in unsubmerged orifice flow, contraction scour was also computed by substituting estimates for the depth of flow at the downstream bridge face in the contraction scour equations. Results with respect to these substitutions are provided in appendix F.

Abutment scour was computed by use of the HIRE equation (Richardson and Davis, 1995, p. 49, equation 29) because the HIRE equation is recommended when the length to depth ratio of the embankment blocking flow exceeds 25. Variables for the Froehlich equation include the Froude number of the flow approaching the embankments, the length of the embankment blocking flow, and the depth of flow approaching the embankment less any roadway overtopping. 


\section{Scour Results}

100-yr discharge 500-yrdischarge

Incipient

Contraction scour:

(Scour depths in feet)

Main channel

Live-bed scour

Clear-water scour

Depth to armoring

Left overbank

Right overbank

Local scour:

Abutment scour

16.0

6.2

9.8

Left abutment

$10.7-$

$6.0-$

Right abutment

Pier scour

Pier 1

Pier 2

\section{$1.72 .1^{-}$}

0.1

$\overline{--}$

$2.0^{-}$

$--$

--

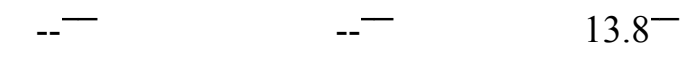

$\overline{-}$

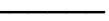

Pier 3

\section{Riprap Sizing}

Abutments:

Left abutment

Right abutment

Piers:

Pier 1

Pier 2

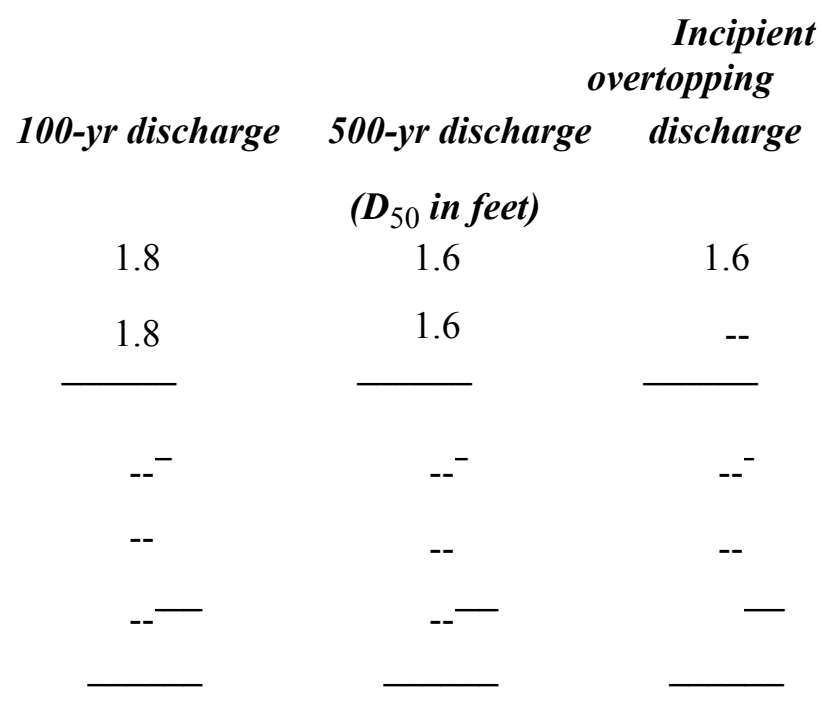




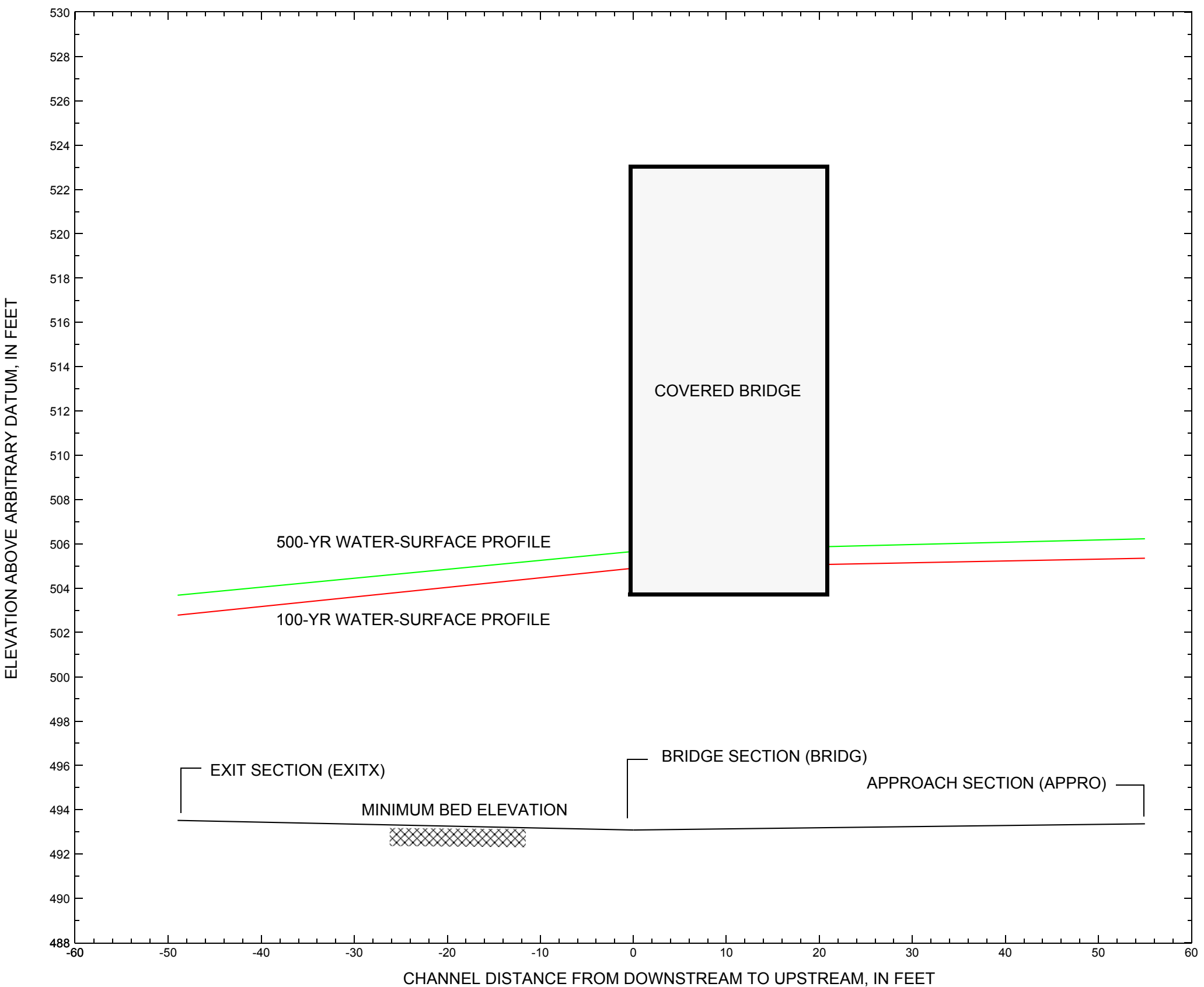

Figure 7. Water-surface profiles for the 100- and 500-yr discharges at structure WWINTH00300033 on Town Highway 30, crossing Mill Brook, West Windsor, Vermont. 


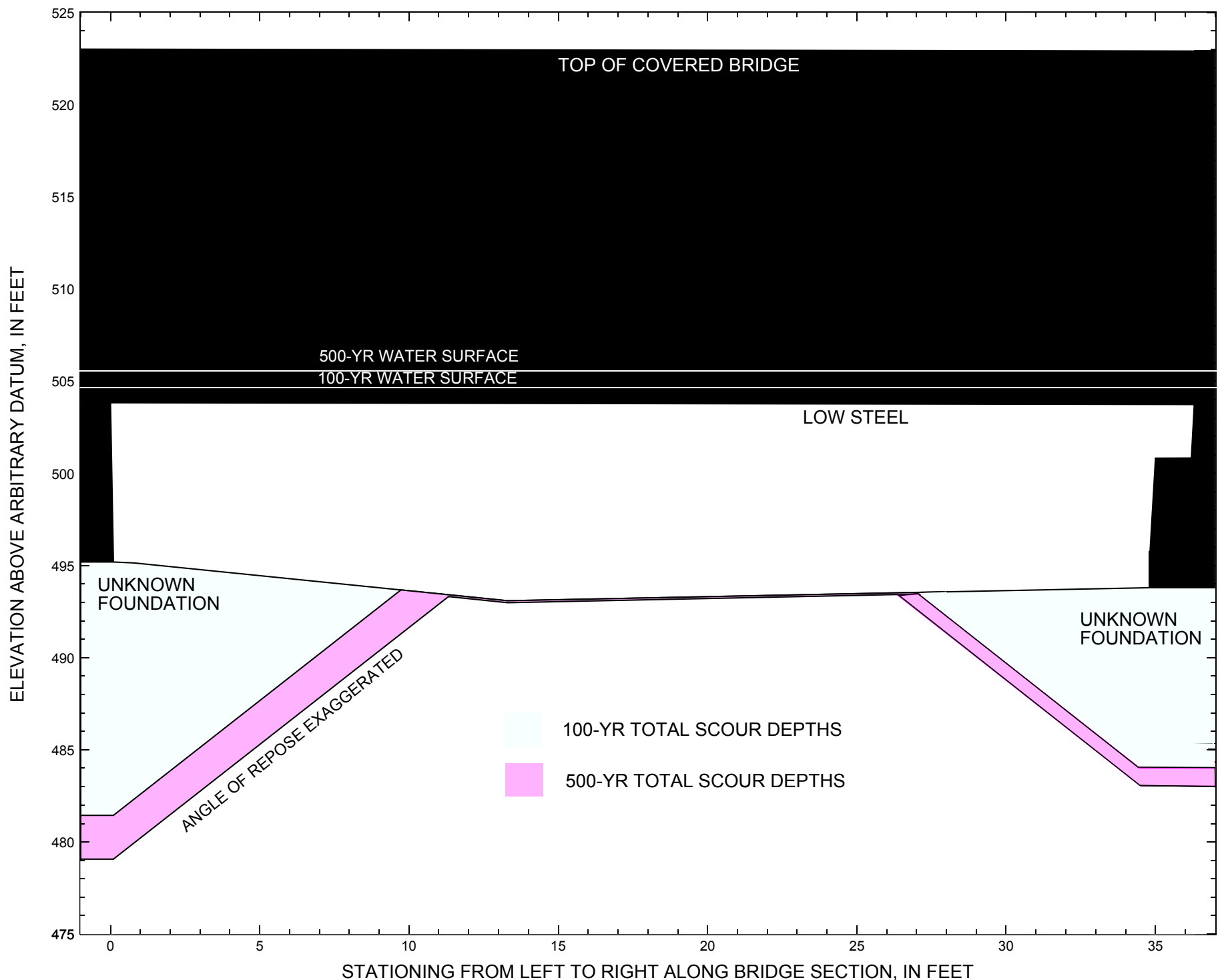

Figure 8. Scour elevations for the 100-yr and 500-yr discharges at structure WWINTH00300033 on Town Highway 30, crossing Mill Brook, West Windsor, Vermont. 
Table 1. Remaining footing/pile depth at abutments for the 100-yr discharge at structure WWINTH00300033 on Town Highway 30, crossing Mill Brook, West Windsor, Vermont.

[VTAOT, Vermont Agency of Transportation; --, no data]

\begin{tabular}{|c|c|c|c|c|c|c|c|c|c|c|c|}
\hline Description & Station $^{1}$ & $\begin{array}{c}\text { FEMA } \\
\text { minimum } \\
\text { low-chord } \\
\text { elevation, } \\
\text { sea level } \\
\text { (feet) }\end{array}$ & $\begin{array}{l}\text { Surveyed } \\
\text { minimum } \\
\text { low-chord } \\
\text { elevation } \\
\text { (feet) }\end{array}$ & $\begin{array}{c}\text { Bottom of } \\
\text { footing/pile } \\
\text { elevation }{ }^{2} \\
\text { (feet) }\end{array}$ & $\begin{array}{c}\text { Channel } \\
\text { elevation at } \\
\text { abutment/ } \\
\text { pier }^{2} \\
\text { (feet) }\end{array}$ & $\begin{array}{l}\text { Contraction } \\
\text { scour depth } \\
\text { (feet) }\end{array}$ & $\begin{array}{l}\text { Abutment } \\
\text { scour } \\
\text { depth } \\
\text { (feet) }\end{array}$ & $\begin{array}{l}\text { Pier } \\
\text { scour } \\
\text { depth } \\
\text { (feet) }\end{array}$ & $\begin{array}{l}\text { Depth of } \\
\text { total scour } \\
\text { (feet) }\end{array}$ & $\begin{array}{c}\text { Elevation of } \\
\text { scour }^{2} \\
\text { (feet) }\end{array}$ & $\begin{array}{c}\text { Remaining } \\
\text { footing/pile } \\
\text { depth } \\
\text { (feet) }\end{array}$ \\
\hline \multicolumn{12}{|c|}{100 -yr discharge is 4,750 cubic-feet per second } \\
\hline Left abutment & 0.0 & 721.9 & 503.8 & -- & 495.2 & 0.0 & 13.8 & -- & 13.8 & 481.4 & -- \\
\hline Right abutment & 36.3 & 721.8 & 503.7 & -- & 493.8 & 0.0 & 9.8 & -- & 9.8 & 484.0 & -- \\
\hline
\end{tabular}

1.Measured along the face of the most constricting side of the bridge.

2.Arbitrary datum for this study.

Table 2. Remaining footing/pile depth at abutments for the 500-yr discharge at structure WWINTH00300033 on Town Highway 30, crossing Mill Brook, West Windsor, Vermont.

[VTAOT, Vermont Agency of Transportation; --, no data]

\begin{tabular}{|c|c|c|c|c|c|c|c|c|c|c|c|}
\hline Description & Station $^{1}$ & $\begin{array}{l}\text { FEMA } \\
\text { minimum } \\
\text { low-chord } \\
\text { elevation, } \\
\text { sea level } \\
\text { (feet) }\end{array}$ & $\begin{array}{l}\text { Surveyed } \\
\text { minimum } \\
\text { low-chord } \\
\text { elevation }{ }^{2} \\
\text { (feet) }\end{array}$ & $\begin{array}{c}\text { Bottom of } \\
\text { footing/pile } \\
\text { elevation }{ }^{2} \\
\text { (feet) }\end{array}$ & $\begin{array}{c}\text { Channel } \\
\text { elevation at } \\
\text { abutment/ } \\
\text { pier }^{2} \\
\text { (feet) }\end{array}$ & $\begin{array}{l}\text { Contraction } \\
\text { scour depth } \\
\text { (feet) }\end{array}$ & $\begin{array}{l}\text { Abutment } \\
\text { scour } \\
\text { depth } \\
\text { (feet) }\end{array}$ & $\begin{array}{l}\text { Pier } \\
\text { scour } \\
\text { depth } \\
\text { (feet) }\end{array}$ & $\begin{array}{l}\text { Depth of } \\
\text { total scour } \\
\text { (feet) }\end{array}$ & $\begin{array}{c}\text { Elevation of } \\
\text { scour }^{2} \\
\text { (feet) }\end{array}$ & $\begin{array}{c}\text { Remaining } \\
\text { footing/pile } \\
\text { depth } \\
\text { (feet) }\end{array}$ \\
\hline \multicolumn{12}{|c|}{500 -yr discharge is 6,490 cubic-feet per second } \\
\hline Left abutment & 0.0 & 721.9 & 503.8 & -- & 495.2 & 0.1 & 16.0 & -- & 16.1 & 479.1 & -- \\
\hline Right abutment & 36.3 & 721.8 & 503.7 & -- & 493.8 & 0.1 & 10.7 & -- & 10.8 & 483.0 & -- \\
\hline
\end{tabular}

1.Measured along the face of the most constricting side of the bridge.

2.Arbitrary datum for this study. 


\section{SELECTED REFERENCES}

Arcement, G.J., Jr., and Schneider, V.R., 1989, Guide for selecting Manning's roughness coefficients for natural channels and flood plains: U.S. Geological Survey Water-Supply Paper 2339, 38 p.

Barnes, H.H., Jr., 1967, Roughness characteristics of natural channels: U.S. Geological Survey Water-Supply Paper 1849, 213 p.

Benson, M. A., 1962, Factors Influencing the Occurrence of Floods in a Humid Region of Diverse Terrain: U.S. Geological Survey Water-Supply Paper $1580-\mathrm{B}, 64 \mathrm{p}$.

Brown, S.A. and Clyde, E.S., 1989, Design of riprap revetment: Federal Highway Administration Hydraulic Engineering Circular No. 11, Publication FHWA-IP-89-016, 156 p.

Federal Highway Administration, 1983, Runoff estimates for small watersheds and development of sound design: Federal Highway Administration Report FHWA-RD-77-158.

Federal Highway Administration, 1993, Stream Stability and Scour at Highway Bridges: Participant Workbook: Federal Highway Administration Report FHWA-HI-91-011.

Federal Emergency Management Agency, 1991, Flood Insurance Study, Town of West Windsor, Windsor County, Vermont: Washington, D.C., June $17,1991$.

Froehlich, D.C., 1989, Local scour at bridge abutments in Ports, M.A., ed., Hydraulic Engineering--Proceedings of the 1989 National Conference on Hydraulic Engineering: New York, American Society of Civil Engineers, p. 13-18.

Hayes, D.C.,1993, Site selection and collection of bridge-scour data in Delaware, Maryland, and Virginia: U.S. Geological Survey Water-Resources Investigation Report 93-4017, 23 p.

Interagency Advisory Committee on Water Data, 1982, Guidelines for determining flood flow frequency: U.S. Geological Survey, Bulletin 17B of the Hydrology Subcommittee, $190 \mathrm{p}$.

Johnson, C.G. and Tasker, G.D.,1974, Progress report on flood magnitude and frequency of Vermont streams: U.S. Geological Survey Open-File Report 74-130, $37 \mathrm{p}$.

Lagasse, P.F., Schall, J.D., Johnson, F., Richardson, E.V., Chang, F., 1995, Stream Stability at Highway Structures: Federal Highway Administration Hydraulic Engineering Circular No. 20, Publication FHWA-IP-90-014, 144 p.

Laursen, E.M., 1960, Scour at bridge crossings: Journal of the Hydraulics Division, American Society of Civil Engineers, v. 86, no. HY2, p. $39-53$.

Potter, W. D., 1957a, Peak rates of runoff in the Adirondack, White Mountains, and Maine woods area, Bureau of Public Roads

Potter, W. D., 1957b, Peak rates of runoff in the New England Hill and Lowland area, Bureau of Public Roads

Richardson, E.V. and Davis, S.R., 1995, Evaluating scour at bridges: Federal Highway Administration Hydraulic Engineering Circular No. 18, Publication FHWA-IP-90-017, 204 p.

Richardson, E.V., Simons, D.B., and Julien, P.Y., 1990, Highways in the river environment: Federal Highway Administration Publication FHWA-HI90-016.

Ritter, D.F., 1984, Process Geomorphology: W.C. Brown Co., Debuque, Iowa, 603 p.

Shearman, J.O., 1990, User's manual for WSPRO--a computer model for water surface profile computations: Federal Highway Administration Publication FHWA-IP-89-027, 187 p.

Shearman, J.O., Kirby, W.H., Schneider, V.R., and Flippo, H.N., 1986, Bridge waterways analysis model; research report: Federal Highway Administration Publication FHWA-RD-86-108, 112 p.

Talbot, A.N., 1887, The determination of water-way for bridges and culverts.

U.S. Geological Survey, 1929, Claremont, New Hampshire 15 Minute Series quadrangle map: U.S. Geological Survey Topographic Maps, Scale $1: 62,500$

U.S. Geological Survey, 1929, Ludlow, Vermont 15 Minute Series quadrangle map: U.S. Geological Survey Topographic Maps, Scale 1:62.500. 


\section{APPENDIX A: \\ WSPRO INPUT FILE}




\section{WSPRO INPUT FILE}

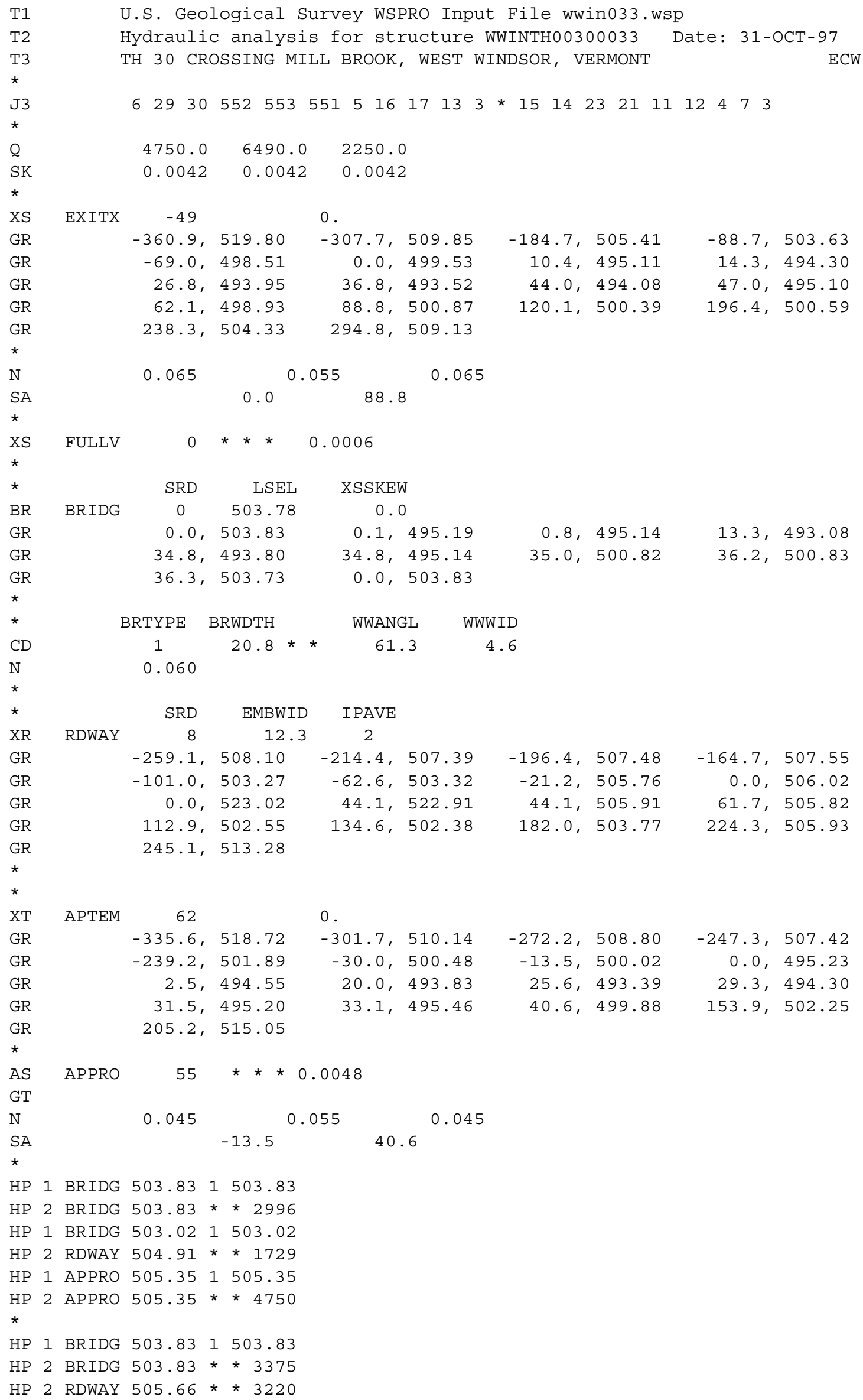




\section{APPENDIX B: \\ WSPRO OUTPUT FILE}


WSPRO OUTPUT FILE

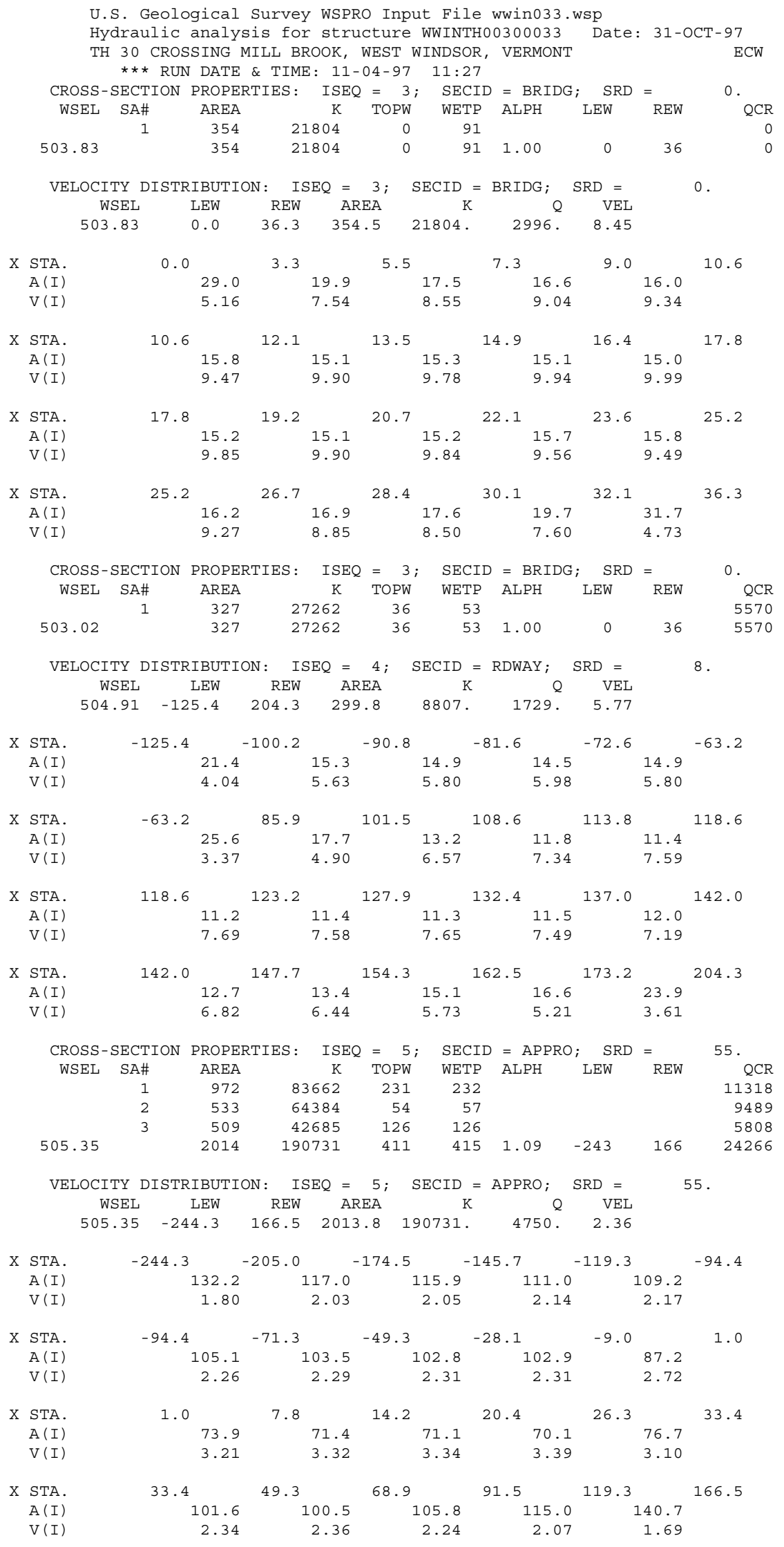


WSPRO OUTPUT FILE (continued)

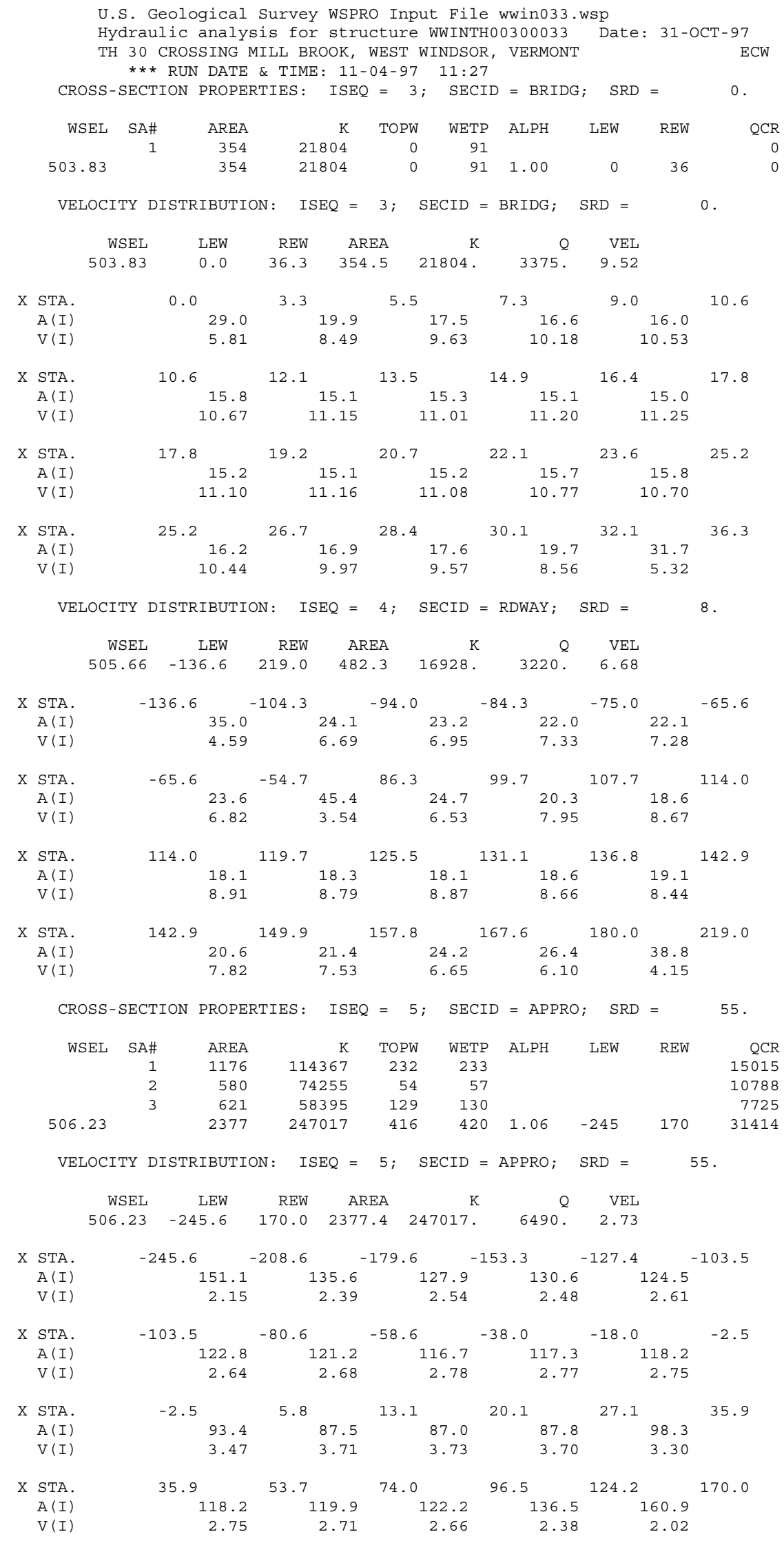


WSPRO OUTPUT FILE (continued)

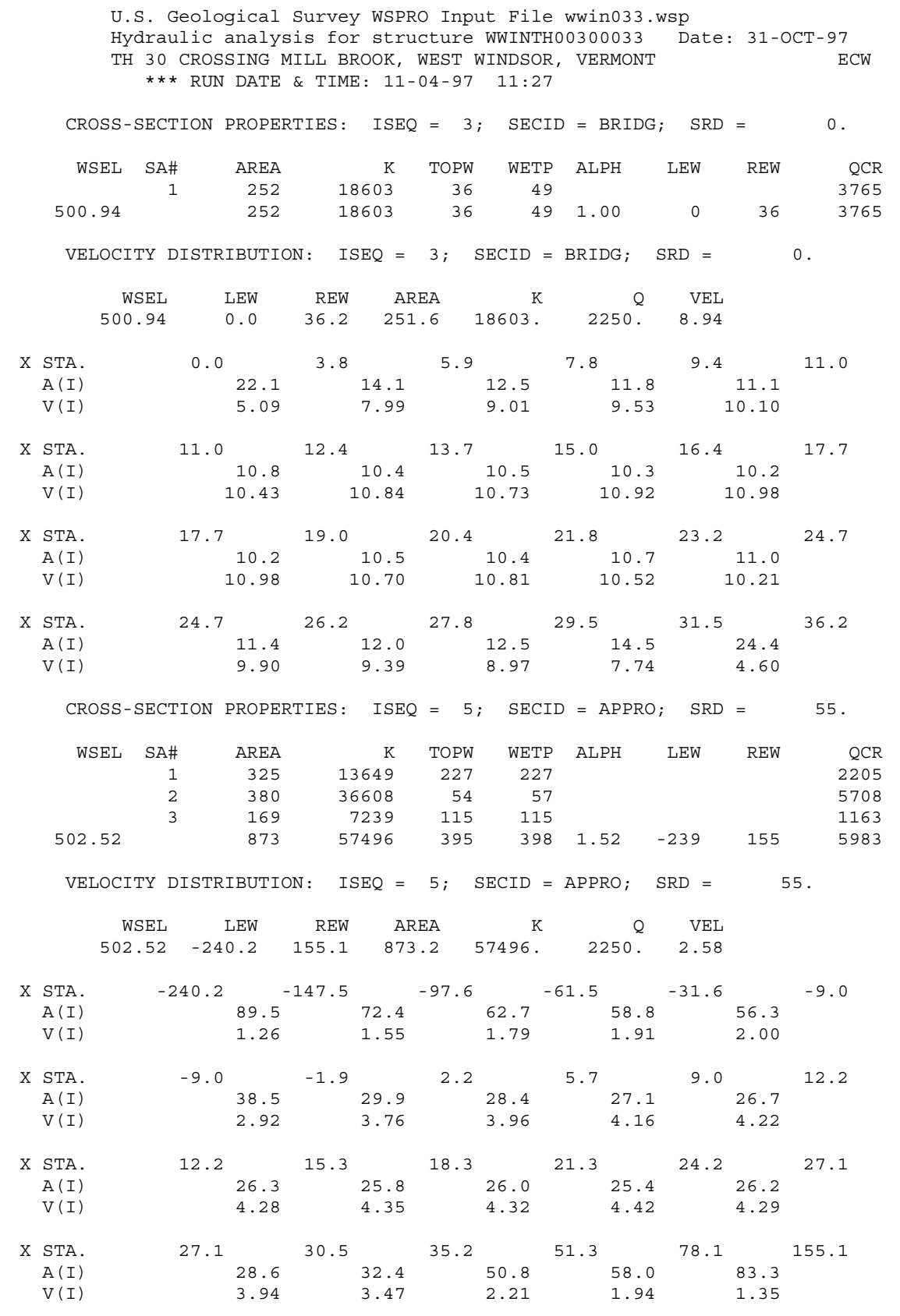


WSPRO OUTPUT FILE (continued)

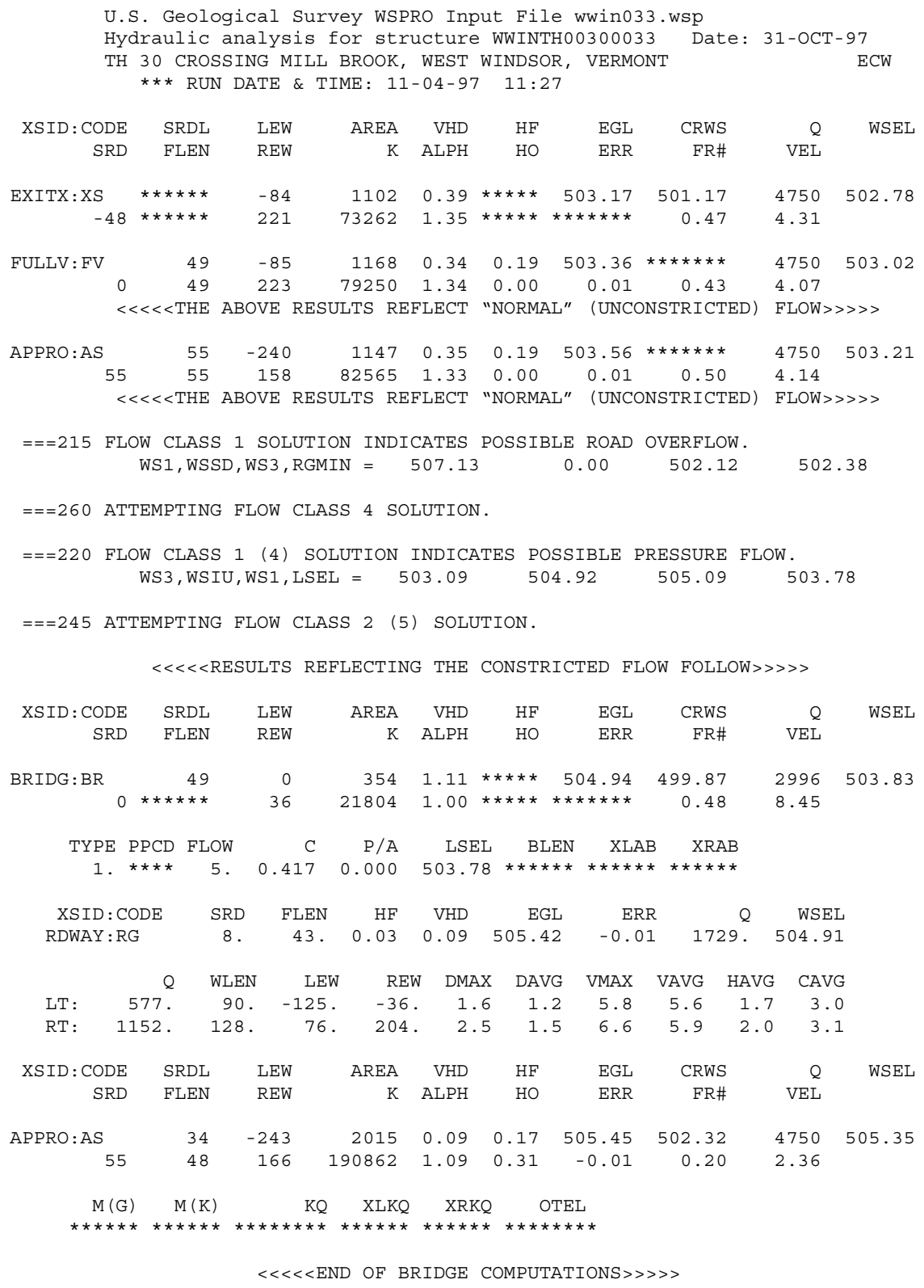

FIRST USER DEFINED TABLE.

\begin{tabular}{|c|c|c|c|c|c|c|c|c|}
\hline XSID : CODE & SRD & LEW & REW & Q & $\mathrm{K}$ & AREA & VEL & WSEL \\
\hline EXITX:XS & -49 & -85 & 221. & 4750 . & 73262 . & 1102. & 4.31 & 502.78 \\
\hline FULLV : FV & 0 . & -86 & 223. & 4750 . & 79250. & 1168. & 4.07 & 503.02 \\
\hline BRIDG : BR & 0 . & 0 & 36 . & 2996. & 21804 . & 354 . & 8.45 & 503.83 \\
\hline RDWAY : RG & $8 . *$ & $\star \star \star \star \star \star *$ & 577. & 1729. & 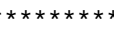 & $* \star * \star * *$ & 2.00 & 504.91 \\
\hline APPRO: AS & 55. & -244 & 166. & 4750 . & 190862 . & 2015 . & 2.36 & 505.35 \\
\hline XSID : CODE & XLKQ & XRKQ & & & & & & \\
\hline
\end{tabular}

SECOND USER DEFINED TABLE.

$\begin{array}{lcrrrrrrrr}\text { XSID : CODE } & \text { CRWS } & \text { FR\# } & \text { YMIN } & \text { YMAX } & \text { HF } & \text { HO } & \text { VHD } & \text { EGL } & \text { WSEL } \\ \text { EXITX:XS } & 501.17 & 0.47 & 493.52 & 519.80 * * * * * * * * * * & 0.39 & 503.17 & 502.78 \\ \text { FULLV:FV } & * * * * * * * & 0.43 & 493.55 & 519.83 & 0.19 & 0.00 & 0.34 & 503.36 & 503.02 \\ \text { BRIDG: BR } & 499.87 & 0.48 & 493.08 & 503.83 * * * * * * * * * * & 1.11 & 504.94 & 503.83 \\ \text { RDWAY: RG } & * * * * * * * * * * * * * * & 502.38 & 523.02 & 0.03 * * * * * * & 0.09 & 505.42 & 504.91 \\ \text { APPRO:AS } & 502.32 & 0.20 & 493.36 & 518.69 & 0.17 & 0.31 & 0.09 & 505.45 & 505.35\end{array}$


WSPRO OUTPUT FILE (continued)

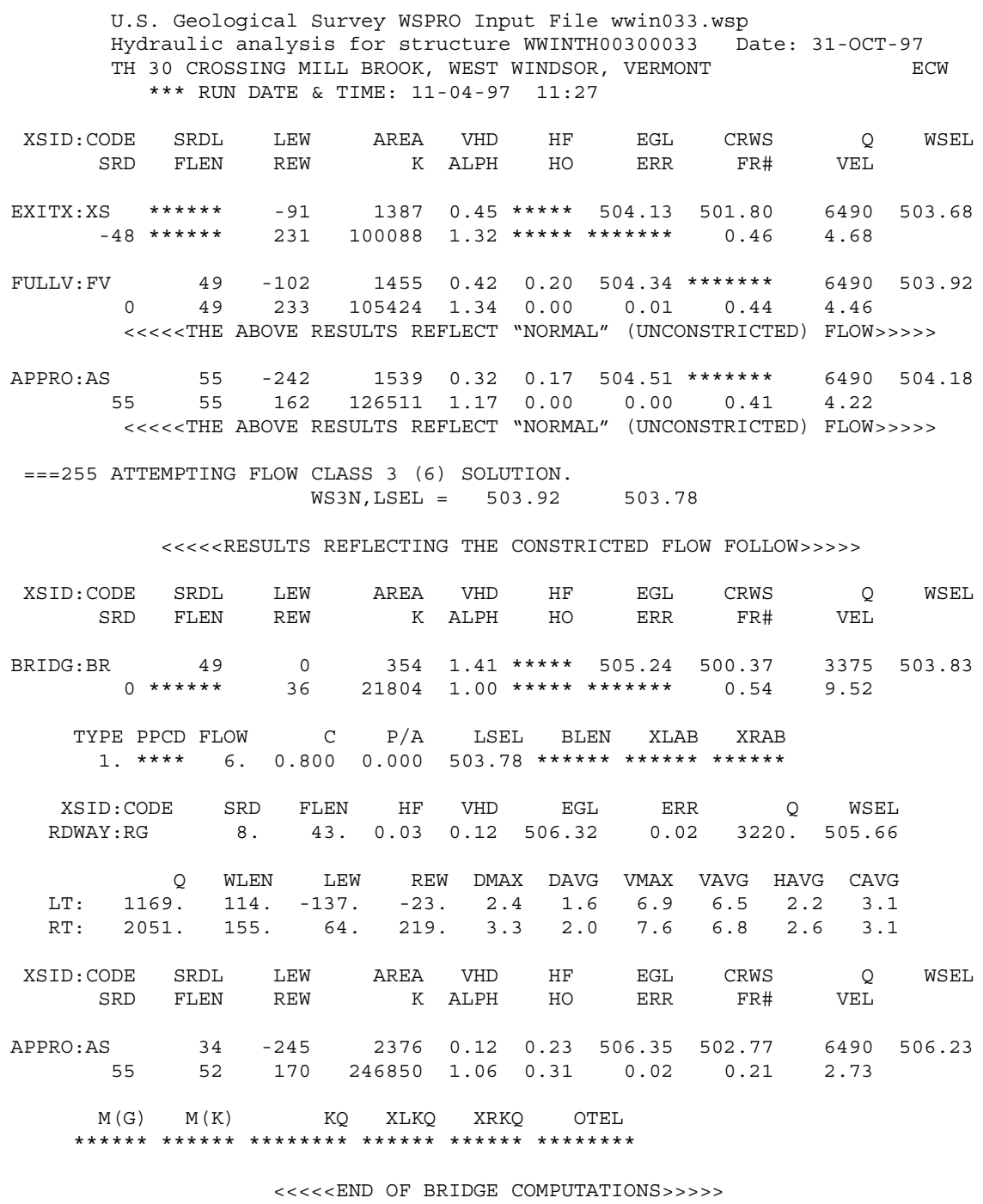

FIRST USER DEFINED TABLE.

\begin{tabular}{|c|c|c|c|c|c|c|c|c|}
\hline XSID : CODE & SRD & LEW & REW & $Q$ & $\mathrm{~K}$ & AREA & VEL & WSEL \\
\hline EXITX:XS & -49 & -92 & 231. & 6490. & 100088. & 1387. & 4.68 & 503.68 \\
\hline FULLV : FV & 0 & -103. & 233. & 6490. & 105424 . & 1455. & 4.46 & 503.92 \\
\hline BRIDG : BR & 0 . & 0 & 36. & 3375 . & 21804 . & 354 . & 9.52 & 503.83 \\
\hline RDWAY : RG & 8.* & $\star \star \star \star \star * *$ & 1169. & 3220 . & 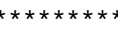 & $* * * * * *$ & 2.00 & 505.66 \\
\hline APPRO: AS & 55. & -246 & 170 & 6490. & 246850 & 2376 . & 2.73 & 506.23 \\
\hline XSID : CODE & XLKQ & XRKQ & & & & & & \\
\hline
\end{tabular}

SECOND USER DEFINED TABLE.

$\begin{array}{lcrrrrrrrr}\text { XSID : CODE } & \text { CRWS } & \text { FR\# } & \text { YMIN } & \text { YMAX } & \text { HF } & \text { HO } & \text { VHD } & \text { EGL } & \text { WSEL } \\ \text { EXITX: XS } & 501.80 & 0.46 & 493.52 & 519.80 * * * * * * * * * * & 0.45 & 504.13 & 503.68 \\ \text { FULLV:FV } & * * * * * * * * & 0.44 & 493.55 & 519.83 & 0.20 & 0.00 & 0.42 & 504.34 & 503.92 \\ \text { BRIDG: BR } & 500.37 & 0.54 & 493.08 & 503.83 * * * * * * * * * * * & 1.41 & 505.24 & 503.83 \\ \text { RDWAY: RG } & * * * * * * * * * * * * * * * & 502.38 & 523.02 & 0.03 * * * * * * & 0.12 & 506.32 & 505.66 \\ \text { APPRO:AS } & 502.77 & 0.21 & 493.36 & 518.69 & 0.23 & 0.31 & 0.12 & 506.35 & 506.23\end{array}$


WSPRO OUTPUT FILE (continued)

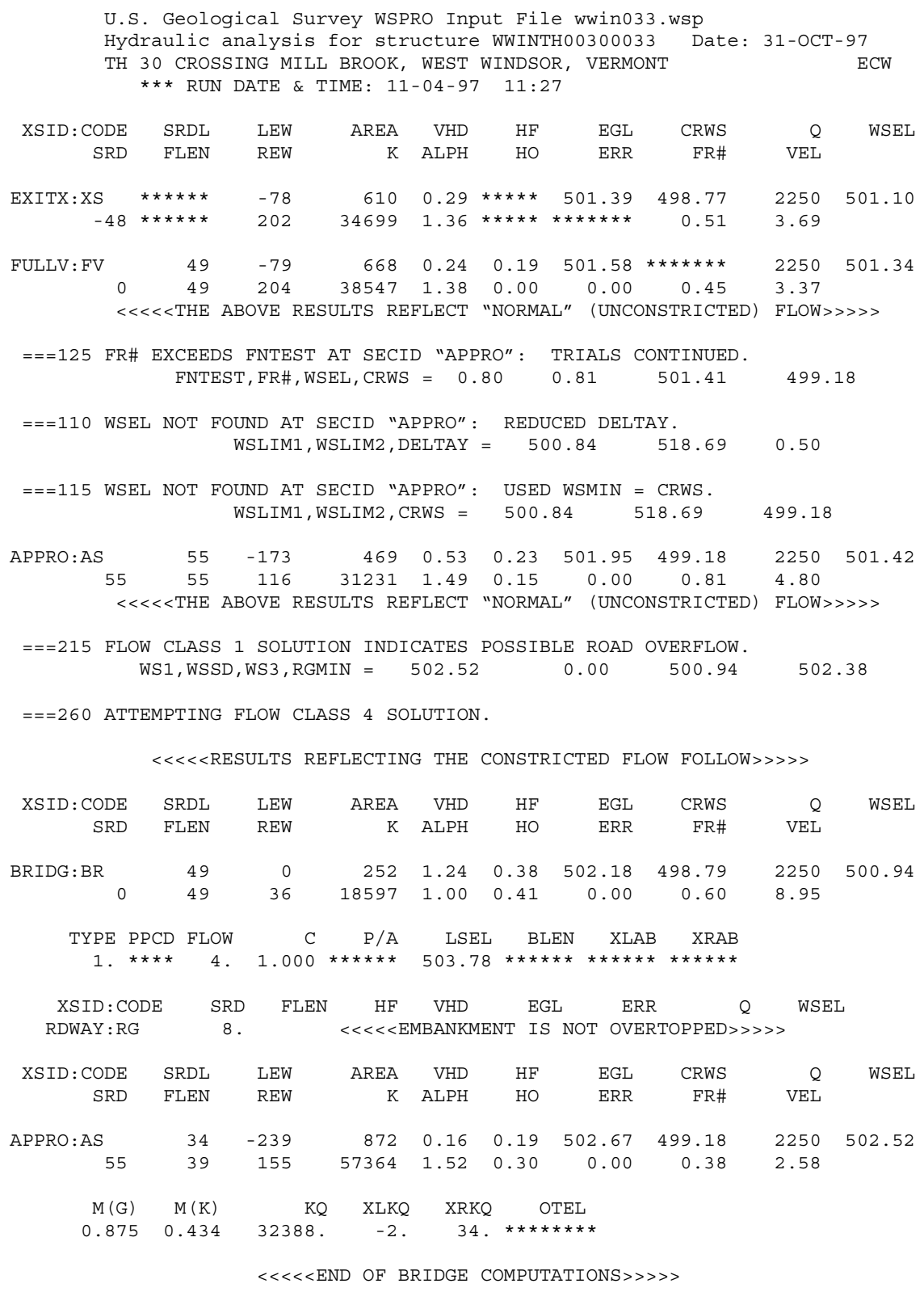

FIRST USER DEFINED TABLE.

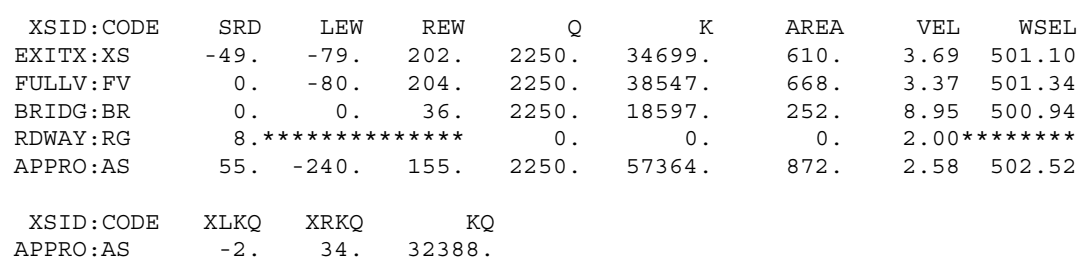

SECOND USER DEFINED TABLE.

\begin{tabular}{|c|c|c|c|c|c|c|c|c|c|}
\hline XSID : CODE & CRWS & FR\# & YMIN & YMAX & $\mathrm{HF}$ & $\mathrm{HO}$ & VHD & EGL & WSEL \\
\hline EXITX:XS & 498.77 & 0.51 & 493.52 & 519.80 * & $* \star \star \star \star \star \star *$ & $\star \star \star \star \star *$ & 0.29 & 501.39 & 501.10 \\
\hline FULLV : FV & 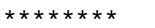 & 0.45 & 493.55 & 519.83 & 0.19 & 0.00 & 0.24 & 501.58 & 501.34 \\
\hline BRIDG : BR & 498.79 & 0.60 & 493.08 & 503.83 & 0.38 & 0.41 & 1.24 & 502.18 & 500.9 \\
\hline RDWAY : RG & 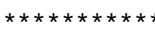 & $\star \star \star * * *$ & 502.38 & 523.02 & $0.07 *$ & $* \star * * *$ & 0.16 & $502.60 *$ & $\star \star \star \star *$ \\
\hline APPRO:AS & 499.18 & 0.38 & 493.36 & 518.69 & 0.19 & 0.30 & 0.16 & 502.67 & 502.5 \\
\hline
\end{tabular}

NORMAL END OF WSPRO EXECUTION. 


\section{APPENDIX C:}

\section{BED-MATERIAL PARTICLE-SIZE DISTRIBUTION}




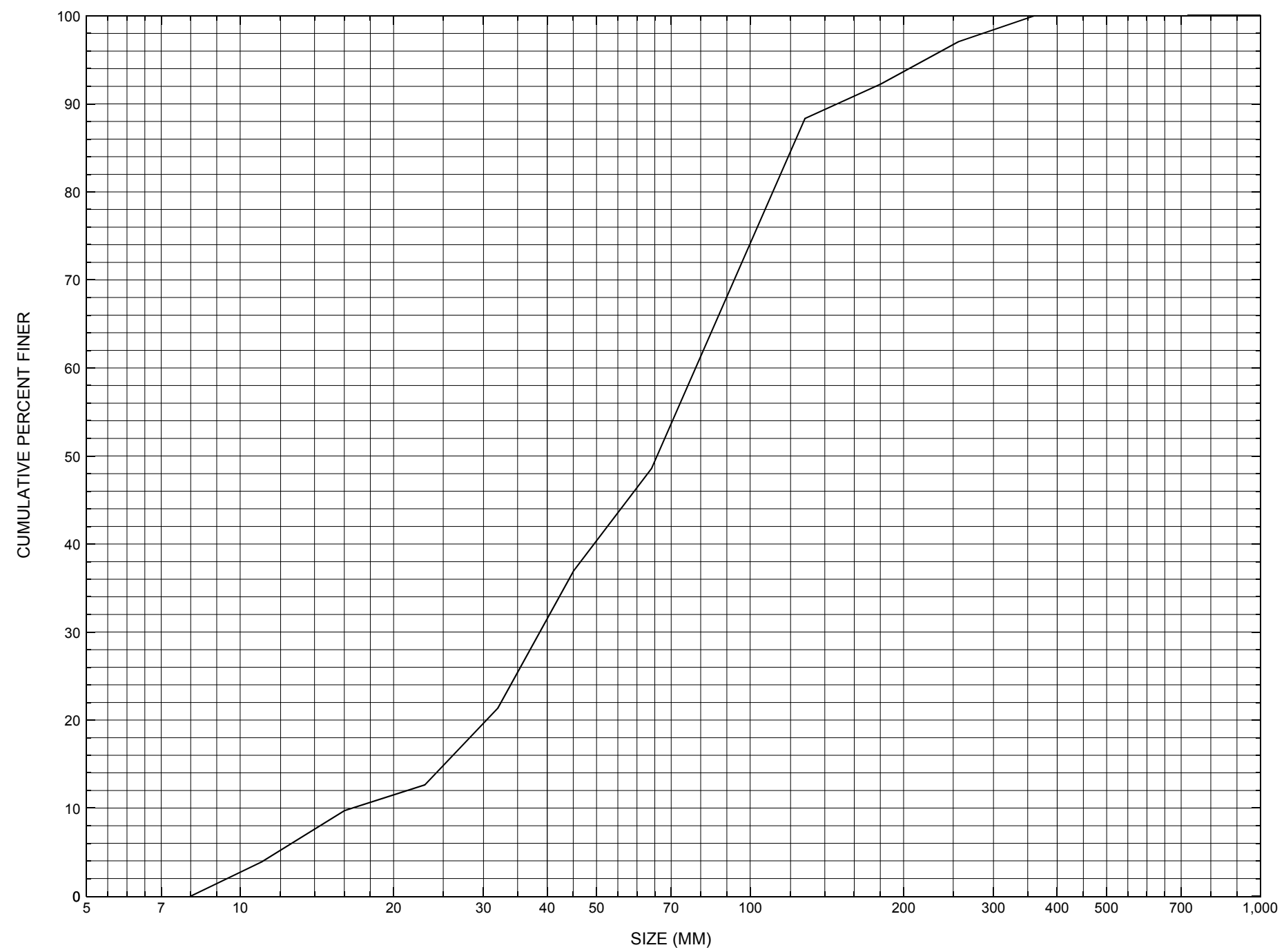

Appendix C. Bed material particle-size distribution for a pebble count in the channel approach of structure WWINTH00300033, in West Windsor, Vermont. 


\section{APPENDIX D: \\ HISTORICAL DATA FORM}




\section{Structure Number WWINTH00300033}

\section{General Location Descriptive}

Data collected by (First Initial, Full last name) $\mathbf{E}$. BOEHMLER

Date $(M M / D D / Y Y) \_\mathbf{0 3} / \underline{23} / \underline{95}$

Highway District Number (I - 2; nn) $\mathbf{0 4}$

Town (FIPS place code; I - 4; nnnnn) $\mathbf{8 3 0 5 0}$

Waterway (I - 6) MILL BROOK

Route Number $\underline{\text { TH030 }}$

Topographic Map Mt.Ascutney

Latitude (I - 16; nnnn.n) $\mathbf{4 3 2 7 3}$
County (FIPS county code; I - 3; nnn)

Mile marker (I - 11; nnn.nnn) $\mathbf{0 0 0 0 0 0}$

Road Name (I - 7): -

Vicinity (I - 9) 0.35 MI TO JCT W VT44

Hydrologic Unit Code: $\mathbf{0 1 0 8 0 1 0 4}$

Longitude (i - 17; nnnnn.n) $\mathbf{7 2 3 1 0}$

\section{Select Federal Inventory Codes}

FHWA Structure Number $(I$ - 8) $\mathbf{1 0 1 4 2 2 0 0 3 3 1 4 2 2}$

Maintenance responsibility $(I-21 ; n n) \quad \mathbf{0 3}$

Year built (I - 27; YYYY) 1919

Average daily traffic, ADT (I - 29; nnnnnn) 000100

Year of ADT (I - 30; YY) $\mathbf{9 1}$

Opening skew to Roadway $(I-34 ; n n) \quad \mathbf{0 0}$

Operational status $(I-41 ; X) \quad \mathbf{P}$

Structure type (I - 43; nnn) $\mathbf{7 1 2}$

Approach span structure type (I - 44; nnn) $\mathbf{0 0 0}$

Number of spans (I - 45; nnn) $\mathbf{0 0 1}$

Number of approach spans (I - 46; nnnn) $\mathbf{0 0 0 0}$

Comments:

The structural inspection report of 11/1/93 indicates the structure is a pressure treated, timber, thru-arch type covered bridge. The abutment walls are constructed of "laid-up" stone with concrete caps, of which the concrete is noted in "like new" condition. The report mentions there are some random areas on the right abutment where voids are evident between some of the stones in the wall. However, the report indicates no significant displacement is evident. The foundation is unknown, and therefore no exposure or undermining of the abutment walls could be reported. Channel scour, bank erosion, and debris accumulation problems are indicated as not evident in this report. (Continued, page 33) 


\section{Bridge Hydrologic Data}

Is there hydrologic data available? $\underline{\mathbf{N}}$ if No, type ctrl-n $h \quad$ VTAOT Drainage area $\left(m i^{2}\right)$ : -

Terrain character:

Stream character \& type: -

Streambed material:

Discharge Data (cfs):

$$
\begin{aligned}
& Q_{2.33}- \\
& Q_{50}-
\end{aligned}
$$

Record flood date $(M M / D D / Y Y)$ :

Estimated Discharge (cfs): Ice conditions (Heavy, Moderate, Light) : -

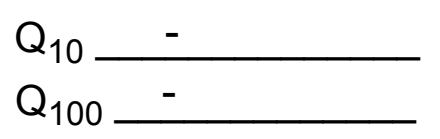

$$
\begin{aligned}
& Q_{25}- \\
& Q_{500}-
\end{aligned}
$$

Water surface elevation $(f t):-$

The stage increases to maximum highwater elevation (Rapidly, Not rapidly):

The stream response is (Flashy, Not flashy):

Describe any significant site conditions upstream or downstream that may influence the stream's stage: -

Watershed storage area (in percent): _ _ \%

The watershed storage area is: - (1-mainly at the headwaters; 2- uniformly distributed; 3-immediatly upstream oi the site)

Water Surface Elevation Estimates for Existing Structure:

\begin{tabular}{|l|l|l|l|l|l|}
\hline Peak discharge frequency & $Q_{2.33}$ & $Q_{10}$ & $Q_{25}$ & $Q_{50}$ & $Q_{100}$ \\
Water surface elevation (ft)) & - & - & - & - & - \\
Velocity (ft/sec) & - & - & - & - & - \\
\hline
\end{tabular}

Long term stream bed changes: -

Is the roadway overtopped below the $\mathrm{Q}_{100}$ ? (Yes, No, Unknown): $\mathbf{U}$ Frequency: Relief Elevation (ft): Discharge over roadway at $Q_{100}\left(f^{3} / \mathrm{sec}\right)$ :

Are there other structures nearby? (Yes, No, Unknown): $\underline{\mathbf{U}}$ Upstream distance (miles): Town: If No or Unknown, type ctrl-n os Highway No. : Structure No. : Year Built:

Clear span (ft): Clear Height $(f t)$ : Full Waterway $\left(f^{2}\right)$ : 
Downstream distance (miles): Town: Year Built:

Highway No. : Structure No. : Structure Type:

Clear span $(f t):$ Clear Height $(f t)$ : Full Waterway $\left(f^{2}\right)$ :

Comments:

The report mentions that there is not much stone fill protection at this site. The waterway makes a slight to moderate bend into the crossing. The streambed material is noted as consisting of stone and gravel with some sand and boulders.

\section{USGS Watershed Data}

Watershed Hydrographic Data

Drainage area $(D A) \stackrel{\mathbf{2 4 . 8 5}}{\mathrm{mi}^{2}}$

Watershed storage (ST)

Bridge site elevation

Main channel length 725 10.53 $10 \%$ channel length elevation $\mathbf{7 8 1}$

Main channel slope (S) 93.56 $\mathrm{ft} / \mathrm{mi}$ $\%$ $\mathrm{mi}$

Lake/pond/swamp area

0.03 $\mathrm{mi}^{2}$

Headwater elevation $\quad \mathbf{3 0 9 3} \mathrm{ft}$ $\mathrm{ft} \quad 85 \%$ channel length elevation $\mathrm{ft}$

Watershed Precipitation Data

Average site precipitation in Average headwater precipitation in

Maximum 2yr-24hr precipitation event $(124,2)$ in

Average seasonal snowfall (Sn) $\mathrm{ft}$ 


\section{Bridge Plan Data}

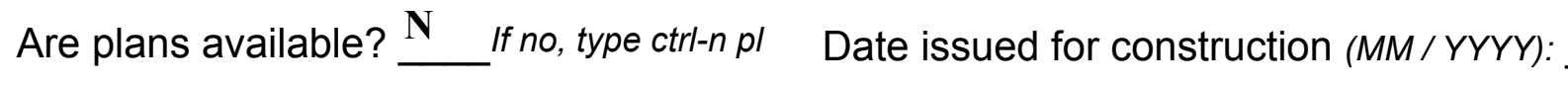

Project Number

Minimum channel bed elevation:

Low superstructure elevation: USLAB DSLAB USRAB DSRAB Benchmark location description:

NO BENCHMARK INFORMATION

Reference Point (MSL, Arbitrary, Other): Datum (NAD27, NAD83, Other):

Foundation Type: 4

If 1 : Footing Thickness

If 2: Pile Type:

If 3: Footing bottom elevation:

Is boring information available? $\mathbf{N}$

Foundation Material Type: $\mathbf{3}$

(1-Spreadfooting; 2-Pile; 3- Gravity; 4-Unknown)

Footing bottom elevation: -

Briefly describe material at foundation bottom elevation or around piles:

NO FOUNDATION MATERIAL INFORMATION

Comments:

NO PLANS. 


\section{Cross-sectional Data}

Is cross-sectional data available? Yes If no, type ctrl-n xs

Source (FEMA, VTAOT, Other)? FEMA

Comments:

\begin{tabular}{|l|l|l|l|l|l|l|l|l|l|l|l|}
\hline Station & $\mathbf{0}$ & $\mathbf{6}$ & $\mathbf{1 2}$ & $\mathbf{1 8}$ & $\mathbf{2 4}$ & $\mathbf{3 0}$ & $\mathbf{3 6}$ & - & - & - & - \\
\hline Feature & LAB & - & - & - & - & - & RAB & - & - & - & - \\
\hline $\begin{array}{l}\text { Low chord } \\
\text { elevation }\end{array}$ & $\mathbf{7 2 1 . 9 0}$ & $\mathbf{7 2 1 . 8 8}$ & $\mathbf{7 2 1 . 8 7}$ & $\mathbf{7 2 1 . 8 5}$ & $\mathbf{7 2 1 . 8 3}$ & $\mathbf{7 2 1 . 8 2}$ & $\mathbf{7 2 1 . 8 0}$ & - & - & - & - \\
\hline $\begin{array}{l}\text { Bed } \\
\text { elevation }\end{array}$ & $\mathbf{7 1 3 . 2 0}$ & $\mathbf{7 1 2 . 1 0}$ & $\mathbf{7 1 1 . 0 0}$ & $\mathbf{7 1 0 . 8 0}$ & $\mathbf{7 1 0 . 5 0}$ & $\mathbf{7 1 1 . 0 0}$ & $\mathbf{7 1 2 . 4 0}$ & - & - & - & - \\
\hline $\begin{array}{l}\text { Low chord } \\
\text { to bed }\end{array}$ & $\mathbf{8 . 7 0}$ & $\mathbf{9 . 7 8}$ & $\mathbf{1 0 . 8 7}$ & $\mathbf{1 1 . 0 5}$ & $\mathbf{1 1 . 3 3}$ & $\mathbf{1 0 . 8 2}$ & $\mathbf{9 . 4 0}$ & - & - & - & - \\
\hline Station & - & - & - & - & - & - & - & - & - & - & - \\
\hline \begin{tabular}{l} 
Feature \\
\hline
\end{tabular} & - & - & - & - & - & - & - & - & - & - & - \\
\hline $\begin{array}{l}\text { Low chord } \\
\text { elevation }\end{array}$ & - & - & - & - & - & - & - & - & - & - & - \\
\hline $\begin{array}{l}\text { Bed } \\
\text { elevation }\end{array}$ & - & - & - & - & - & - & - & - & - & - & - \\
\hline $\begin{array}{l}\text { Low chord } \\
\text { to bed }\end{array}$ & - & - & - & - & - & - & - & - & - & - & - \\
\hline
\end{tabular}

Source (FEMA, VTAOT, Other)?

Comments: -

\begin{tabular}{|l|l|l|l|l|l|l|l|l|l|l|l|}
\hline Station & - & - & - & - & - & - & - & - & - & - & - \\
\hline Feature & - & - & - & - & - & - & - & - & - & - & - \\
\hline $\begin{array}{l}\text { Low chord } \\
\text { elevation }\end{array}$ & - & - & - & - & - & - & - & - & - & - & - \\
\hline $\begin{array}{l}\text { Bed } \\
\text { elevation }\end{array}$ & - & - & - & - & - & - & - & - & - & - & - \\
\hline $\begin{array}{l}\text { Low chord } \\
\text { to bed }\end{array}$ & - & - & - & - & - & - & - & - & - & - & - \\
\hline Station & - & - & - & - & - & - & - & - & - & - & - \\
\hline Feature & - & - & - & - & - & - & - & - & - & - & - \\
\hline $\begin{array}{l}\text { Low chord } \\
\text { elevation }\end{array}$ & - & - & - & - & - & - & - & - & - & - & - \\
\hline $\begin{array}{l}\text { Bed } \\
\text { elevation }\end{array}$ & - & - & - & - & - & - & - & - & - & - & - \\
\hline $\begin{array}{l}\text { Low chord } \\
\text { to bed }\end{array}$ & - & - & - & - & - & - & - & - & - & - & - \\
\hline
\end{tabular}




\section{APPENDIX E: \\ LEVEL I DATA FORM}


U. S. Geological Survey

Bridge Field Data Collection and Processing Form

Qa/Qc Check by: $\underline{\mathbf{R B}}$ Date: $\underline{11 / 20 / 96}$

\section{Structure Number}

WWINTH00300033

Computerized by: $\underline{\mathbf{R B}}$ Date: $\underline{1 / 21 / 97}$

Reviewd by: $\quad$ EW Date: $\underline{12 / 4 / 97}$

\section{A. General Location Descriptive}

1. Data collected by (First Initial, Full last name) R. FLYNN

2. Highway District Number 04

Date $(M M / D D / Y Y) \underline{06} / \underline{05} / \underline{1996}$

County WINDSOR (027)

Mile marker 0000

Waterway (I - 6) MILL BROOK

Town WEST WINDSOR (83050)

Road Name Ely Road

Route Number TH030

Hydrologic Unit Code: $\mathbf{0 1 0 8 0 1 0 4}$

3. Descriptive comments:

The bridge is located 0.35 miles from the junction with VT 44. This is a covered bridge with concrete capped laid-up stone abutments.

\section{B. Bridge Deck Observations}
4. Surface cover... LBUS 4
RBUS 4
LBDS 6
RBDS 6
Overall 5

(2b us, ds,lb,rb: 1- Urban; 2- Suburban; 3- Row crops; 4- Pasture; 5- Shrub- and brushland; 6- Forest; 7- Wetland)
5. Ambient water surface... US 1
UB 1
DS 1
(1- pool; 2- riffle)

6. Bridge structure type 1 (1- single span; 2- multiple span; 3- single arch; 4- multiple arch; 5-cylindrical culvert; 6- box culvert; or 7- other)
7. Bridge length 46
(feet)
Span length $\underline{\mathbf{4 0}}$
(feet)
Bridge width 12.3 (feet)

\section{Road approach to bridge:}

\section{LB 1 RB 1 ( 0 even, 1-lower, 2- higher) \\ 9. LB 2 RB $\underline{2}$ (1-Paved, 2- Not paved)}

10. Embankment slope (run / rise in feet / foot)

US left

US right

\begin{tabular}{|c|c|c|c|}
\hline \multicolumn{2}{|c|}{ Protection } & \multirow{2}{*}{ 13.Erosion } & 14.Severity \\
\hline 11.Type & 12.Cond. & $\underline{\mathbf{2}}$ & $\underline{\mathbf{2}}$ \\
\hline $\mathbf{2}$ & $\underline{\mathbf{2}}$ & $\underline{\mathbf{2}}$ & $\underline{\mathbf{1}}$ \\
\hline $\mathbf{2}$ & $\mathbf{2}$ & $\underline{\mathbf{2}}$ & $\underline{\mathbf{1}}$ \\
\hline $\mathbf{2}$ & $\underline{\mathbf{2}}$ & $\underline{\mathbf{1}}$ \\
\hline
\end{tabular}

Bank protection types: 0- none; 1- < 12 inches;

2- $<36$ inches; $3-<48$ inches

4- < 60 inches; 5- wall / artificial levee

Bank protection conditions: 1- good; 2- slumped;

3- eroded; 4- failed

Erosion: 0 - none; 1- channel erosion; 2 -

road wash; 3- both; 4- other

Erosion Severity: 0 - none; 1- slight; 2- moderate; 3- severe

Channel approach to bridge (BF):

15. Angle of approach: 15

16. Bridge skew: 10

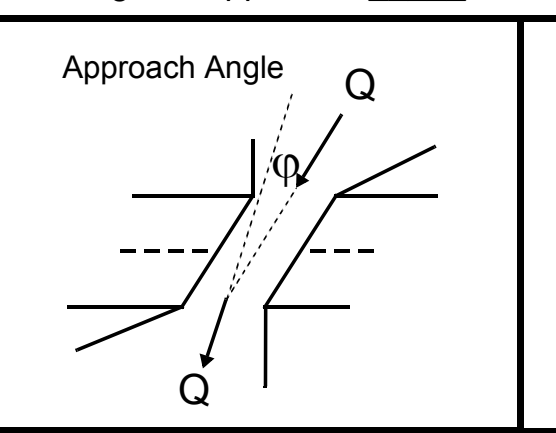

17. Channel impact zone 1:

Where? RB $(L B, R B)$

Exist? $\underline{\mathbf{Y}}(\mathrm{Y}$ or $N)$ Bridge Skew Angle

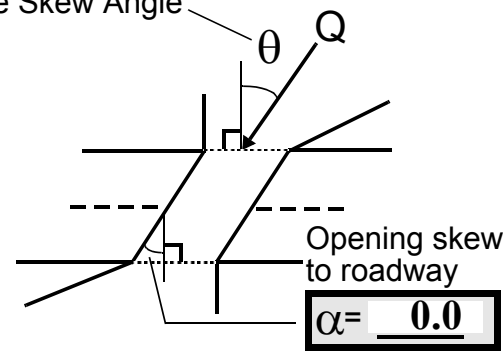

Range? 40 feet $\underline{\text { US }}$

Severity 1

Channel impact zone 2:

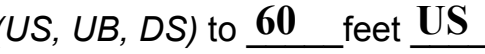

Where? LB (LB, RB)

Exist? $\underline{\mathbf{Y}}(\mathrm{Y}$ or $N)$

Range? 20 feet $\underline{\text { DS }}$

Severity 1

Impact Severity: 0- none to very slight; 1- Slight; 2- Moderate; 3- Severe 
18. Bridge Type: 1a

1a- Vertical abutments with wingwalls

1 b- Vertical abutments without wingwalls

2- Vertical abutments and wingwalls, sloping embankment Wingwalls parallel to abut. face

3- Spill through abutments

4- Sloping embankment, vertical wingwalls and abutments

Wingwall angle less than $90^{\circ}$.

19. Bridge Deck Comments (surface cover variations, measured bridge and span lengths, bridge type variations, approach overflow width, etc.)

5. The US riffle ends approximately at the approach section at $45 \mathrm{ft}$ US. The riffle begins again DS at the exit section, about $40 \mathrm{ft}$ DS.

4. There are shrubs along the left bank DS and along both banks US.

18. There are only two wingwalls, on the US right and DS left. They are constructed of laid-up stone.

On the left bank US, there is a gully formation in the embankment where sand is eroding near the abutment.

\section{Upstream Channel Assessment}

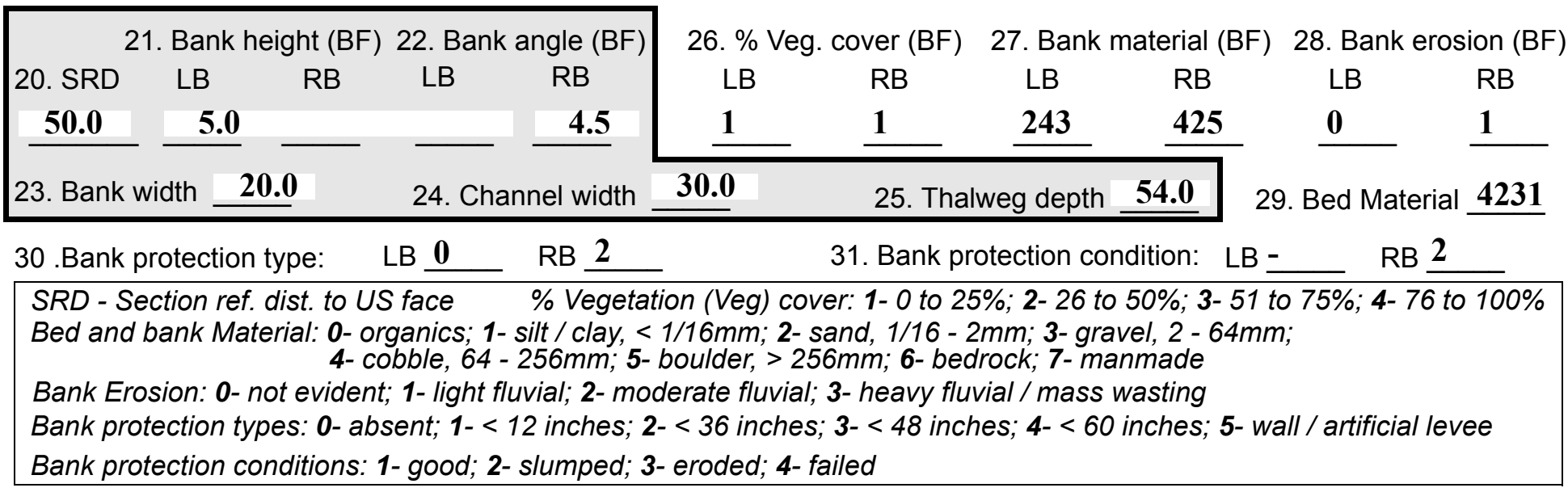

32. Comments (bank material variation, minor inflows, protection extent, etc.):

30. The right bank protection extends from the bridge abutment to $40 \mathrm{ft}$ US. 
36. Point bar extent: $\mathbf{0}$ feet US (US, UB) to $\mathbf{5 0}$ feet $\underline{\mathbf{U S}}$ (US, UB, DS) positioned $\mathbf{0}$ \%LB to $\mathbf{2 0}$ $\%$ RB

37. Material: $\mathbf{2 1}$

38. Point or side bar comments (Circle Point or Side; Note additional bars, material variation, status, etc.):

39. Is a cut-bank present? $\mathbf{Y}$ (Y or if $N$ type ctrl-n cb) 40. Where? $\mathbf{R B}$ (LB or RB)

41. Mid-bank distance: 45 42. Cut bank extent: 35 US, UB) to $\mathbf{6 0}$ feet $\underline{\mathbf{U S}}$ (US, UB, DS)

43. Bank damage: 1 (1- eroded and/or creep; 2- slip failure; 3- block failure)

44. Cut bank comments (eg. additional cut banks, protection condition, etc.):

Moderate erosion with cobbles and some debris on the cut bank.

45. Is channel scour present? $\mathbf{N}$ ( $Y$ or if $N$ type ctrl-n cs)

47. Scour dimensions: Length Width Depth : 46. Mid-scour distance: -

48. Scour comments (eg. additional scour areas, local scouring process, etc.):

\section{NO CHANNEL SCOUR}

49. Are there major confluences? $\mathbf{N}$

51. Confluence 1: Distance Confluence 2: Distance 52. Enters on Enters on 54. Confluence comments (eg. confluence name):

NO MAJOR CONFLUENCES
50. How many? -

53. Type(1- perennial; 2- ephemeral)

Type (1-perennial; 2-ephemeral) ( $L B$ or $R B)$

\section{Under Bridge Channel Assessment}

55. Channel restraint (BF)? LB 2

\begin{tabular}{|ccccc}
\hline \multicolumn{2}{|c}{ 56. Height (BF) } & \multicolumn{3}{c}{57 Angle (BF) } \\
LB & RB & LB & RB \\
$\mathbf{3 3 . 0}$ & & & $\mathbf{2 . 0}$ & \\
\hline
\end{tabular}

58. Bank width (BF) (1- natural bank; 2- abutment; 3- artificial levee)

Bed and bank Material: 0- organics; 1- silt / clay, < 1/16mm; 2- sand, 1/16 - 2mm; 3- gravel, 2 - 64mm; 4- cobble, 64 - 256mm; 5- boulder, > 256mm; 6- bedrock; 7- manmade

61. Material $(\mathrm{BF}) \quad$ 62. Erosion $(\mathrm{BF})$

LB RB LB RB

$\underline{2} \quad \underline{7} \quad \underline{7}$

59. Channel width - 60. Thalweg depth $\lcm{\mathbf{9 0 . 0}}$

63. Bed Material -

Bank Erosion: 0- not evident; 1- light fluvial; 2- moderate fluvial; 3- heavy fluvial / mass wasting

64. Comments (bank material variation, minor inflows, protection extent, etc.):

2543 
65. Debris and Ice Is there debris accumulation?

67. Debris Potential (1- Low; 2- Moderate; 3- High)

69. Is there evidence of ice build-up? 1

70. Debris and Ice Comments:
$(Y$ or $N)$ 66. Where? $\mathbf{N}$

68. Capture Efficiency 2

(1- Upstream; 2- At bridge; 3-Both)

Ice Blockage Potential $\underline{\mathbf{N}}$
(1- Low; 2- Moderate; 3- High)

(1-Low; 2- Moderate; 3- High) 1

\begin{tabular}{|l|c|c|c|c|c|c|c|c|}
\hline Abutments & $\begin{array}{c}\text { 71. Attack } \\
\angle \text { (BF) }\end{array}$ & $\begin{array}{c}\text { 72. Slope } \angle \\
\text { (Qmax) }\end{array}$ & $\begin{array}{c}\text { 73. Toe } \\
\text { loc. (BF) }\end{array}$ & $\begin{array}{c}\text { 74. Scour } \\
\text { Condition }\end{array}$ & $\begin{array}{c}\text { 75. Scour } \\
\text { depth }\end{array}$ & $\begin{array}{c}\text { 76. Exposure } \\
\text { depth }\end{array}$ & 77. Material & 78. Length \\
\hline LABUT & & $\mathbf{3 0}$ & $\mathbf{9 0}$ & $\mathbf{2}$ & $\mathbf{0}$ & - & - & $\mathbf{9 0 . 0}$ \\
\hline RABUT & $\mathbf{2}$ & - & $\mathbf{9 0}$ & & & $\mathbf{2}$ & $\mathbf{0}$ & $\mathbf{3 6 . 5}$ \\
\hline
\end{tabular}

Pushed: $L B$ or RB

Toe Location (Loc.): 0- even, 1- set back, 2- protrudes

Scour cond.: 0- not evident; 1- evident (comment); 2- footing exposed; 3-undermined footing; 4- piling exposed; 5- settled; 6- failed

Materials: 1- Concrete; 2- Stone masonry or drywall; 3- steel or metal; 4- wood

79. Abutment comments (eg. undermined penetration, unusual scour processes, debris, etc.):

$-$

2

The left abutment is laid-up stone with a concrete cap. The stone is $6 \mathrm{ft}$ high with a $1.5 \mathrm{ft}$ concrete cap on top. Voids are evident between the stones in the wall, about 1 in to $2 \mathrm{in}$, length and width. There is a foot of sand along the bottom of the abutment. The right abutment is also constructed of $6 \mathrm{ft}$ of laid-up stone with a $2 \mathrm{ft}$ high concrete cap on top. Larger voids are evident between stones in the wall about 1 in to 4 in, length and width. The channel bottom is covered in cobbles and boulders which is underlain by sand.

80. Wingwalls:

$\begin{array}{llll} & & & \\ \text { Exist? Material? } & \text { Scour } & \text { Scour } & \text { Exposure } \\ \text { Condition? } & \text { depth? } & \text { depth? }\end{array}$

USLWW:

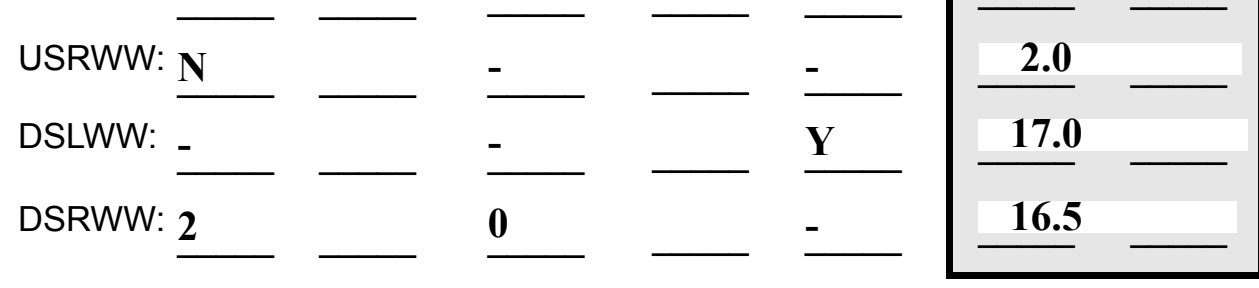

Wingwall materials: 1- Concrete; 2- Stone masonry or drywall; 3- steel or metal; 4- wood

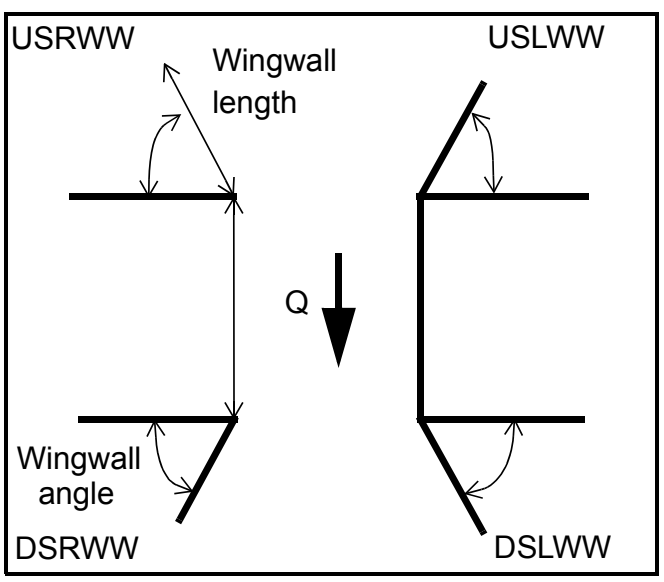

82. Bank / Bridge Protection:

\begin{tabular}{|l|l|l|l|l|l|l|l|c|}
\hline Location & USLWW & USRWW & LABUT & RABUT & LB & RB & DSLWW & DSRWW \\
\hline Type & - & $\mathbf{0}$ & $\mathbf{N}$ & - & - & $\mathbf{2}$ & - & $\mathbf{2}$ \\
\hline Condition & $\mathbf{Y}$ & - & - & - & - & $\mathbf{1}$ & - & $\mathbf{1}$ \\
\hline Extent & $\mathbf{2}$ & - & - & - & $\mathbf{2}$ & $\mathbf{0}$ & $\mathbf{2}$ & - \\
\hline
\end{tabular}

Bank / Bridge protection types: 0- absent; 1- < 12 inches; 2- < 36 inches; 3- < 48 inches; 4- < 60 inches; 
83. Wingwall and protection comments (eg. undermined penetration, unusual scour processes, etc.):

-
-
-
-
-
2
2
1
-
-
-

\section{Piers:}

84. Are there piers? Th (Y or if N type ctrl-n pr)

\begin{tabular}{|l|c|c|c|l|l|l|l|}
\hline \multirow{2}{*}{$\begin{array}{l}85 . \\
\text { Pier no. }\end{array}$} & \multicolumn{3}{|c|}{ width (w) feet } & \multicolumn{3}{c|}{ elevation (e) feet } \\
\cline { 2 - 8 } & w1 & w2 & w3 & e@w1 & e@w2 & e@w3 \\
\hline Pier 1 & - & & $\mathbf{9 . 5}$ & - & $\mathbf{6 0 . 0}$ & $\mathbf{7 5 . 0}$ \\
\hline Pier 2 & $\mathbf{8 . 0}$ & - & - & - & - & - \\
\hline Pier 3 & - & - & - & - & - & - \\
\hline Pier 4 & - & - & - & - & - & - \\
\hline
\end{tabular}

\begin{tabular}{|l|l|l|l|l|}
\hline Level 1 Pier Descr. & \multicolumn{1}{|c|}{1} & \multicolumn{1}{|c|}{2} & \multicolumn{1}{|c|}{3} & \multicolumn{1}{|c|}{4} \\
\hline 86. Location (BF) & e pro- & DS left & h are & nd US \\
\hline 87. Type & tec- & con- & from & alon \\
\hline 88. Material & tion & sists & $\mathbf{1}$ ft & g the \\
\hline 89. Shape & for & of & to 2 & base \\
\hline 90. Inclined? & the & smal & ft & of \\
\hline 91. Attack $\angle$ (BF) & wing & ler & abov & the \\
\hline 92. Pushed & walls & cob- & e the & wing \\
\hline 93. Length (feet) & - & - & - & - \\
\hline 94. \# of piles & on & bles & chan & wall \\
\hline 95. Cross-members & the & to & nel & to \\
\hline 96. Scour Condition & US & boul- & bed & the \\
\hline 97. Scour depth & right & ders & and & bank \\
\hline 98. Exposure depth & and & whic & exte & - It \\
\hline
\end{tabular}

LFP, LTB, LB, MCL, MCM, MCR, RB, RTB, RFP

1- Solid pier, 2- column, 3- bent

1-Wood; 2- concrete; 3- metal; 4- stone

1- Round; 2- Square; 3- Pointed

Y-yes; $N$ - no

$L B$ or $R B$

0- none; 1- laterals; 2- diagonals; 3- both

0- not evident; 1- evident (comment);

2- footing exposed; 3- piling exposed;

4- undermined footing; 5- settled; 6-failed 
99. Pier comments (eg. undermined penetration, protection and protection extent, unusual scour processes, etc.): is the same along the right abutment also.

$\mathbf{N}$

100.

\section{E. Downstream Channel Assessment}

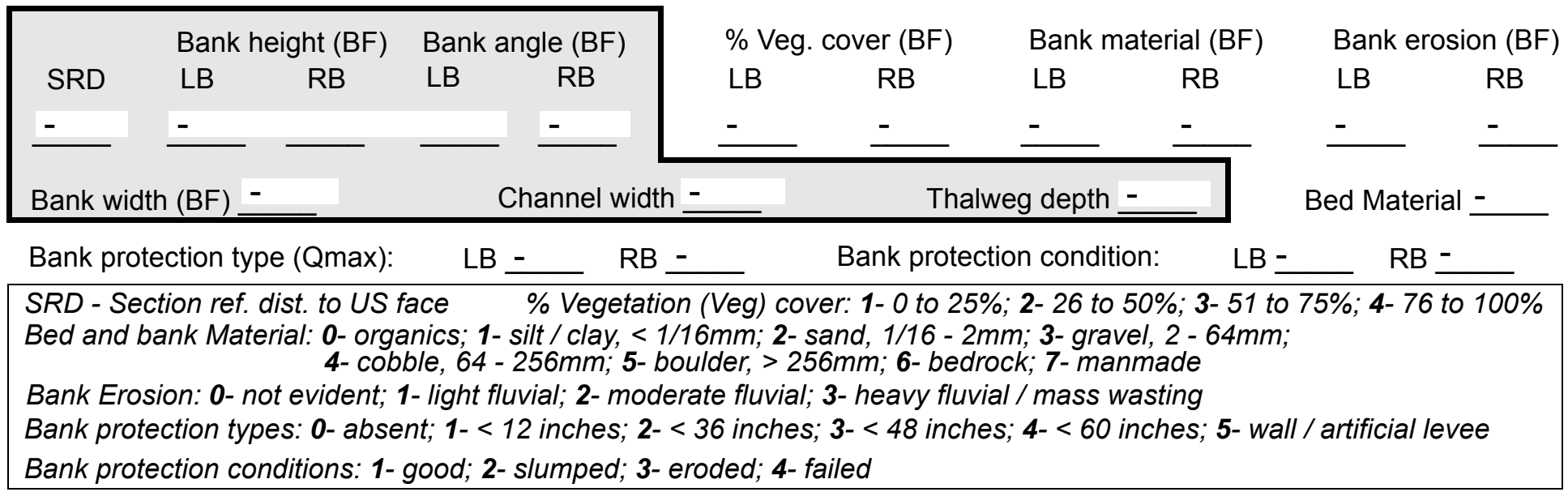

Comments (eg. bank material variation, minor inflows, protection extent, etc.):

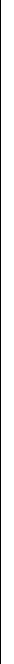

\section{Is a drop structure present? __ ( $Y$ or $N$, if $N$ type ctrl-n $d s) \quad$ 102. Distance: ___ feet}

103. Drop: __ feet 104. Structure material: ___ (1- steel sheet pile; 2- wood pile; 3- concrete; 4- other)

105. Drop structure comments (eg. downstream scour depth): 
106. Point/Side bar present? (Y or $N$. if $N$ type ctrl-n pb)Mid-bar distance: Mid-bar width: -

Point bar extent: feet (US, UB, DS) to feet (US, UB, DS) positioned \%LB to $\%$ RB Material:

Point or side bar comments (Circle Point or Side; note additional bars, material variation, status, etc.):

-

$-$

$\underline{\text { Is a cut-bank present? }} \underline{\mathbf{N}}$ (Y or if N type ctrl-n cb) Where? $\underline{\mathbf{O}}$ (LB or RB) Mid-bank distance: $\underline{\text { PIE }}$ Cut bank extent: $\underline{\mathbf{R S}}$ feet __ (US, UB, DS) to feet (US, UB, DS)

Bank damage: (1- eroded and/or creep; 2- slip failure; 3- block failure)

Cut bank comments (eg. additional cut banks, protection condition, etc.):

Is channel scour present? ( $Y$ or if $N$ type ctrl-n cs)

Mid-scour distance: $\mathbf{3}$ Scour dimensions: Length $\underline{4}$ Width 245 Depth: 245

Positioned $\underline{\mathbf{1}}$ \%LB to $\underline{\mathbf{0}} \% \mathrm{RB}$ Scour comments (eg. additional scour areas, local scouring process, etc.): 4213

0

0

$-$

Are there major confluences? Confluence 1: Distance Enters on ( $(L B$ or $R B)$ How many? -

Confluence 2: Distance

Enters on ( $L B$ or $R B)$

Type (1- perennial; 2- ephemeral)

Confluence comments (eg. confluence name):

\section{F. Geomorphic Channel Assessment}

107. Stage of reach evolution
1- Constructed

2- Stable

3- Aggraded

4- Degraded

5- Laterally unstable

6- Vertically and laterally unstable 
108. Evolution comments (Channel evolution not considering bridge effects; See HEC-20, Figure 1 for geomorphic descriptors):

$\mathbf{N}$

$-$

NO DROP STRUCTURE 


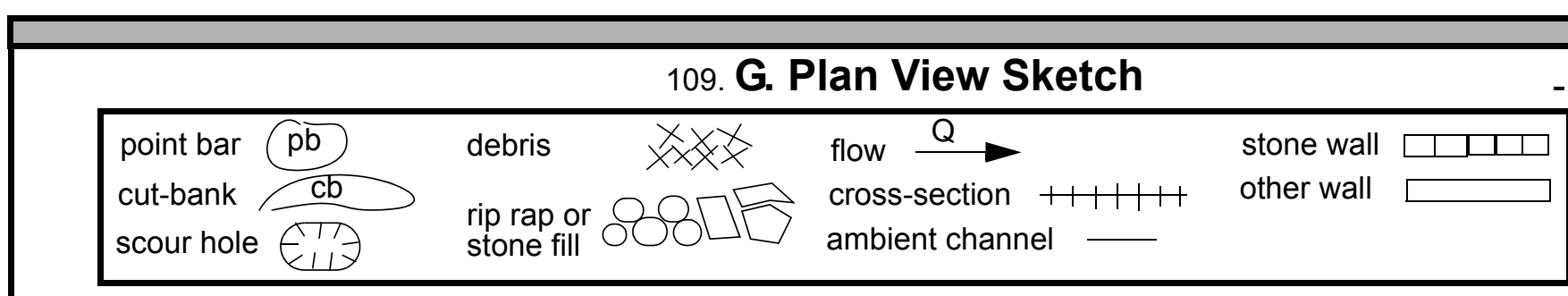


APPENDIX F:

SCOUR COMPUTATIONS 


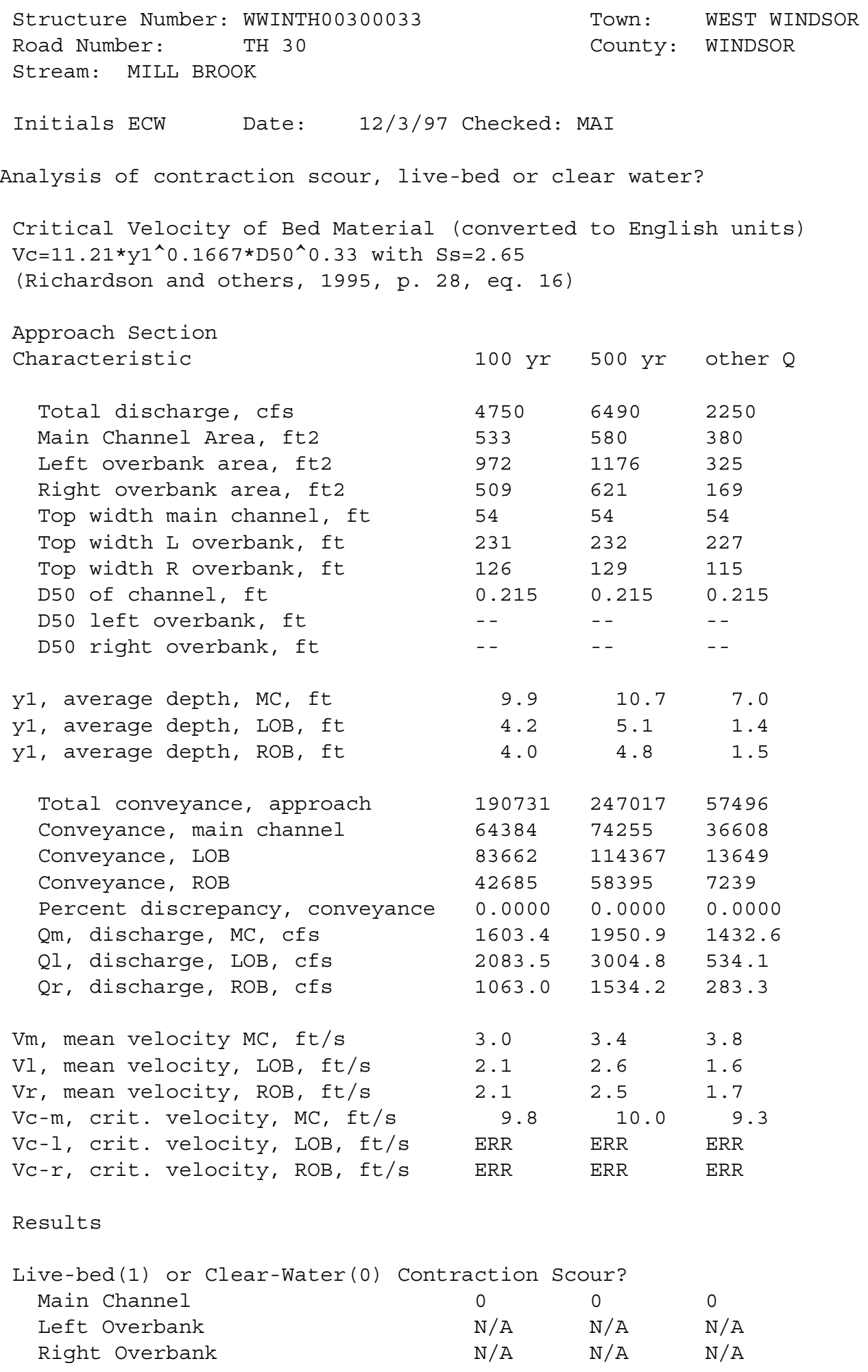


Clear water Contraction Scour in MAIN CHANNEL

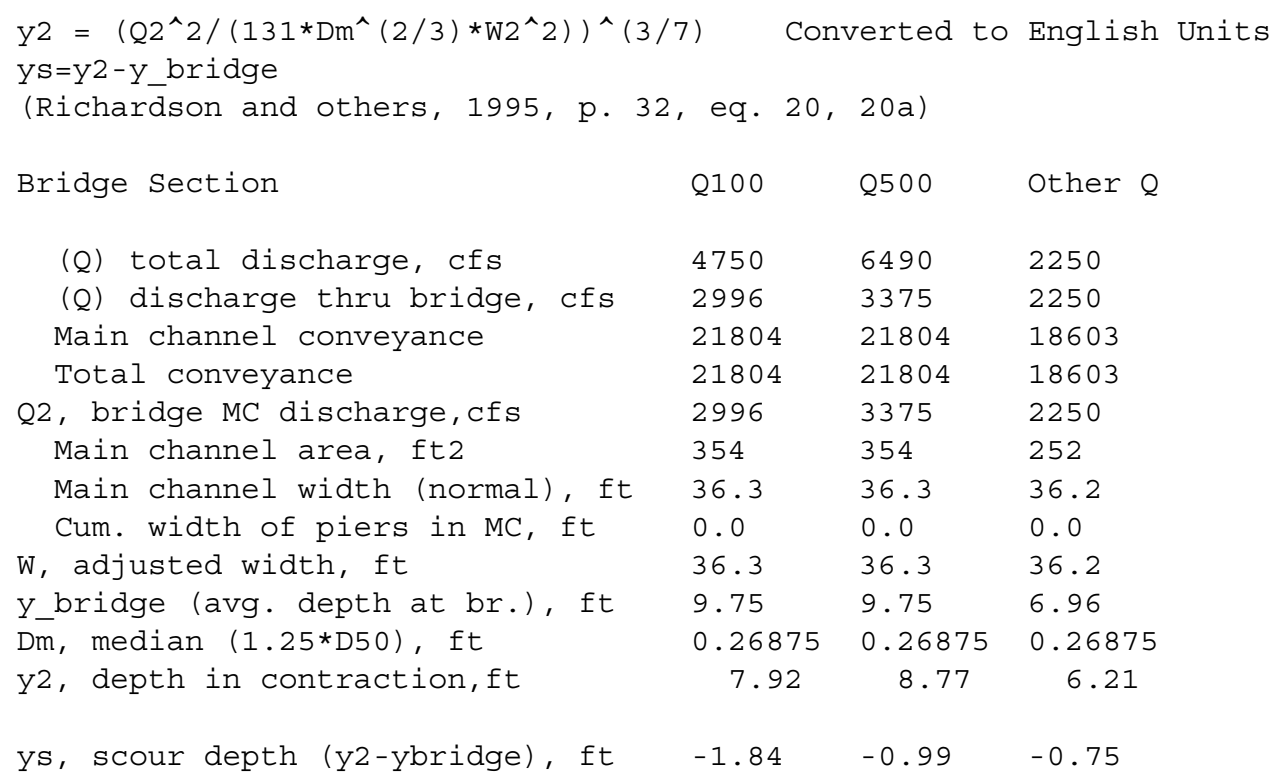

\begin{tabular}{|c|c|c|c|}
\hline \multirow{2}{*}{\multicolumn{4}{|c|}{ Armoring }} \\
\hline & & & \\
\hline \multirow{2}{*}{\multicolumn{4}{|c|}{$\begin{array}{l}\mathrm{DC}=\left[\left(1.94 * \mathrm{~V}^{\wedge} 2\right) /(5.75 * \log (12.27 * \mathrm{y} / \mathrm{D} 90))^{\wedge} 2\right] /[0.03 *(165-62.4)] \\
\text { Depth to Armoring }=3 *(1 / \mathrm{PC}-1)\end{array}$}} \\
\hline & & & \\
\hline (Federal Highway Administration, 19s & 93 ) & & \\
\hline Downstream bridge face property & $100-y r$ & $500-y r$ & Other $Q$ \\
\hline Q, discharge thru bridge MC, cfs & 2996 & 3375 & 2250 \\
\hline Main channel area (DS), ft2 & 327 & 354 & 252 \\
\hline Main channel width (normal), ft & 36.3 & 36.3 & 36.2 \\
\hline Cum. width of piers, ft & 0.0 & 0.0 & 0.0 \\
\hline Adj. main channel width, ft & 36.3 & 36.3 & 36.2 \\
\hline D90, ft & 0.4854 & 0.4854 & 0.4854 \\
\hline D95, ft & 0.7218 & 0.7218 & 0.7218 \\
\hline Dc, critical grain size, ft & 0.2880 & 0.3029 & 0.3014 \\
\hline Pc, Decimal percent coarser than Dc & 0.335 & 0.306 & 0.309 \\
\hline to armoring, ft & 1.72 & 2.06 & 2.03 \\
\hline
\end{tabular}




\begin{tabular}{|c|c|c|c|c|}
\hline $\begin{array}{l}\text { Chang pressure flow equation } \\
\text { Cq=1/Cf*CC Cf=1.5*Fr^0.43 (<=1) } \\
\text { Umbrell pressure flow equation } \\
\text { (Hb+Ys)/ya=1.1021*[(1-w/ya)* (Va/VC) } \\
\text { (Richardson and other, 1995, p. } 144\end{array}$ & $\begin{array}{l}\mathrm{Hb}+\mathrm{Ys}=\mathrm{Cq} \\
\mathrm{CC}=\mathrm{SQRT}[0 \\
]^{\wedge} 0.6031 \\
-146)\end{array}$ & $\begin{array}{l}{ }^{*} \mathrm{qbr} / \mathrm{Vc} \\
0.10(\mathrm{Hb} /\end{array}$ & $(y a-w)-0.56)]+0.79$ & $(<=1)$ \\
\hline & Q100 & Q500 & OtherQ & \\
\hline Q, total, cfs & 4750 & 6490 & 2250 & \\
\hline Q, thru bridge $M C$, cfs & 2996 & 3375 & 2250 & \\
\hline Vc, critical velocity, ft/s & 9.84 & 9.98 & 9.30 & \\
\hline Va, velocity MC approach, ft/s & 3.01 & 3.36 & 3.77 & \\
\hline Main channel width (normal), ft & 36.3 & 36.3 & 36.2 & \\
\hline Cum. width of piers in MC, ft & 0.0 & 0.0 & 0.0 & \\
\hline W, adjusted width, ft & 36.3 & 36.3 & 36.2 & \\
\hline qbr, unit discharge, ft2/s & 82.5 & 93.0 & 62.2 & \\
\hline Area of full opening, ft2 & 354.0 & 354.0 & 252.0 & \\
\hline $\mathrm{Hb}$, depth of full opening, ft & 9.75 & 9.75 & 6.96 & \\
\hline Fr, Froude number, bridge MC & 0.48 & 0.54 & 0 & \\
\hline Cf, Fr correction factor $(<=1.0)$ & 1.00 & 1.00 & 0.00 & \\
\hline **Area at downstream face, ft2 & 327 & $\mathrm{~N} / \mathrm{A}$ & $\mathrm{N} / \mathrm{A}$ & \\
\hline **Hb, depth at downstream face, ft & 9.01 & $\mathrm{~N} / \mathrm{A}$ & $\mathrm{N} / \mathrm{A}$ & \\
\hline **Fr, Froude number at DS face & 0.54 & ERR & ERR & \\
\hline$* * \mathrm{Cf}$, for downstream face $(<=1.0)$ & 1.00 & $\mathrm{~N} / \mathrm{A}$ & $\mathrm{N} / \mathrm{A}$ & \\
\hline Elevation of Low steel, ft & 503.78 & 503.78 & 0 & \\
\hline Elevation of Bed, ft & 494.03 & 494.03 & -6.96 & \\
\hline Elevation of Approach, ft & 505.35 & 506.23 & 0 & \\
\hline Friction loss, approach, ft & 0.17 & 0.23 & 0 & \\
\hline Elevation of WS immediately US, ft & 505.18 & 506.00 & 0.00 & \\
\hline ya, depth immediately US, ft & 11.15 & 11.97 & 6.96 & \\
\hline Mean elevation of deck, ft & 522.96 & 522.96 & 0 & \\
\hline w, depth of overflow, ft $(>=0)$ & 0.00 & 0.00 & 0.00 & \\
\hline Cc, vert contrac correction $(<=1.0)$ & 0.97 & 0.95 & 1.00 & \\
\hline$* *$ CC, for downstream face $(<=1.0)$ & 0.947406 & ERR & ERR & \\
\hline Ys, scour w/Chang equation, ft & -1.08 & 0.06 & $\mathrm{~N} / \mathrm{A}$ & \\
\hline Ys, scour w/Umbrell equation, ft & -3.74 & -2.90 & $\mathrm{~N} / \mathrm{A}$ & \\
\hline
\end{tabular}




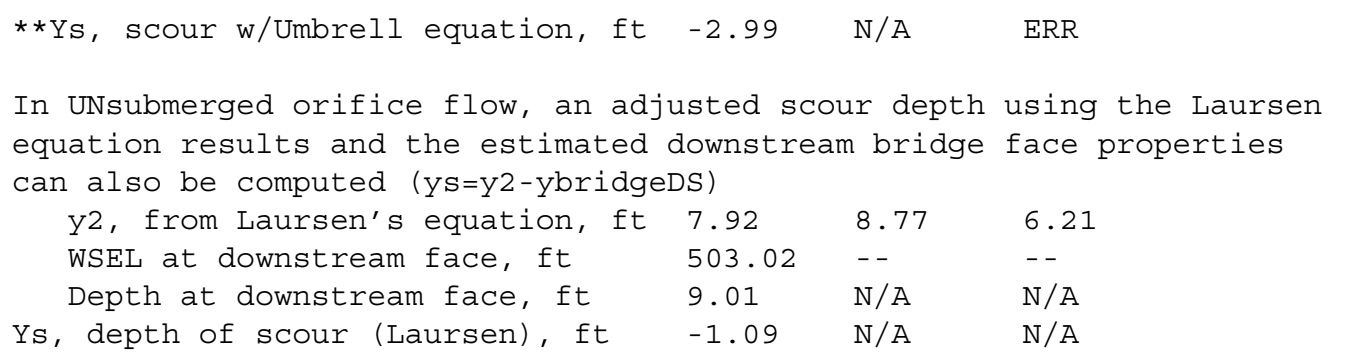

Abutment scour

Froehlich's Abutment Scour

$\mathrm{Ys} / \mathrm{Y} 1=2.27 * \mathrm{~K} 1 * \mathrm{~K} 2 *\left(\mathrm{a}^{\prime} / \mathrm{Y} 1\right)^{\wedge} 0.43 * \mathrm{Fr} 1^{\wedge} 0.61+1$

(Richardson and others, 1995, p. 48, eq. 28)

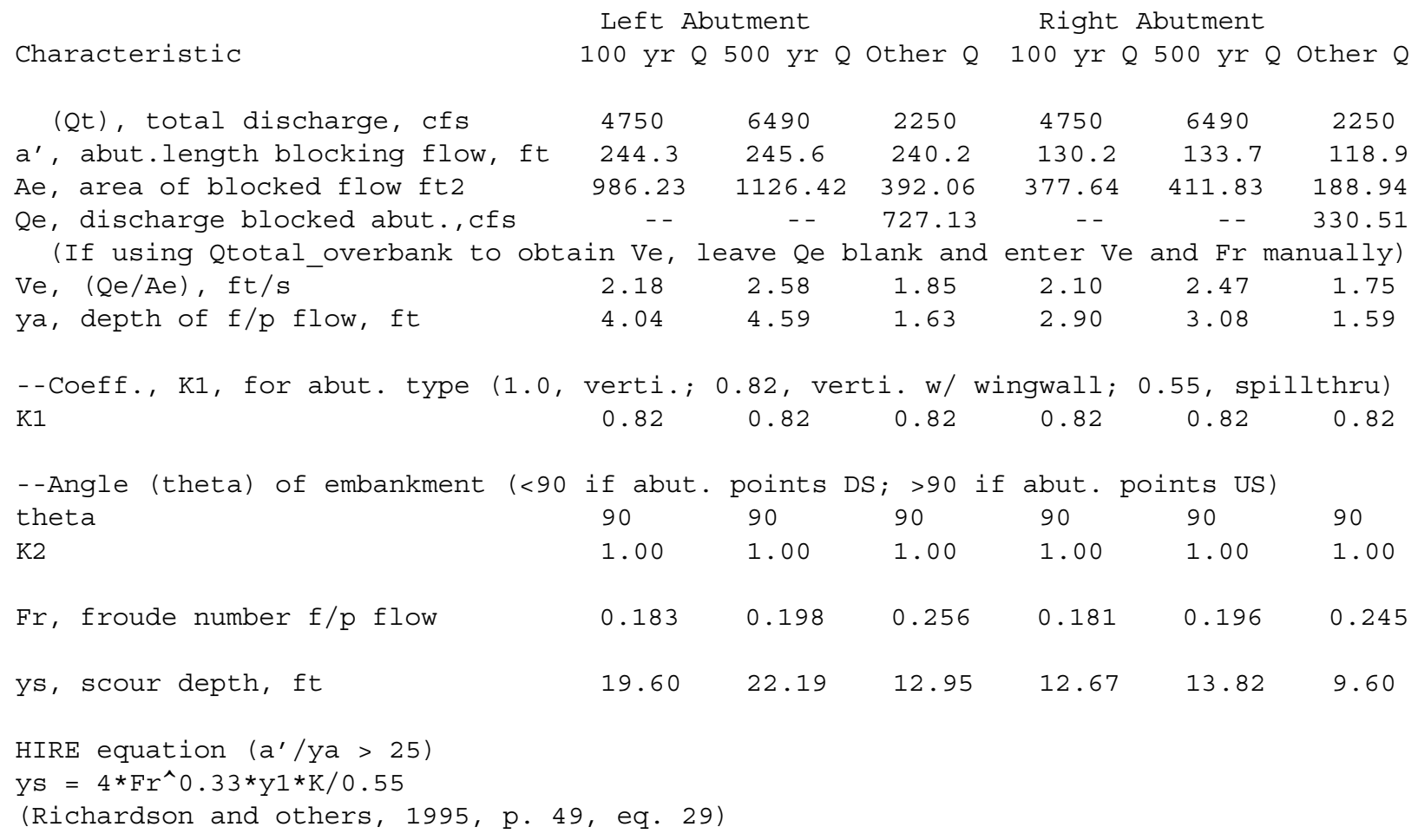




\begin{tabular}{|c|c|c|c|c|c|c|}
\hline$a^{\prime}$ (abut length blocked, ft) & 244.3 & 245.6 & 240.2 & 130.2 & 133.7 & 118.9 \\
\hline y1 (depth f/p flow, ft) & 4.04 & 4.59 & 1.63 & 2.90 & 3.08 & 1.59 \\
\hline$a^{\prime} / y^{\prime}$ & 60.52 & 53.55 & 147.16 & 44.89 & 43.41 & 74.82 \\
\hline Skew correction (p. 49, fig. 16) & 1.00 & 1.00 & 1.00 & 1.00 & 1.00 & 1.00 \\
\hline Froude no. $f / p$ flow & 0.18 & 0.20 & 0.26 & 0.18 & 0.20 & 0.24 \\
\hline $\begin{array}{c}\text { Ys w/ corr. factor } \mathrm{K} 1 / 0.55: \\
\text { vertical }\end{array}$ & 16.76 & 19.55 & 7.57 & 12.00 & 13.08 & \\
\hline vertical w/ ww's & 13.75 & $\begin{array}{l}19.55 \\
16.03\end{array}$ & $\begin{array}{l}1.51 \\
6.21\end{array}$ & 9.84 & $\begin{array}{l}13.08 \\
10.73\end{array}$ & $\begin{array}{l}1.26 \\
5.95\end{array}$ \\
\hline spill-through & 9.22 & 10.75 & 4.16 & 6.60 & 7.20 & 3.99 \\
\hline \multicolumn{7}{|l|}{ Abutment riprap Sizing } \\
\hline \multirow{2}{*}{\multicolumn{7}{|c|}{$\begin{array}{l}\text { Isbash Relationship } \\
\mathrm{D} 50=\mathrm{Y}^{*} \mathrm{~K} * \mathrm{Fr} \mathrm{r}^{\wedge} /(\mathrm{Ss}-1) \text { and } \mathrm{D} 50=\mathrm{Y}^{*} \mathrm{~K} *\left(\mathrm{Fr} r^{\wedge} 2\right)^{\wedge} 0.14 /(\mathrm{Ss}-1) \\
\text { (Richardson and others, 1995, p112, eq. } 81,82)\end{array}$}} \\
\hline & & & & & & \\
\hline Characteristic & Q100 & Q500 & Other Q & Q100 & Q500 & Other $Q$ \\
\hline Fr, Froude Number & 0.54 & 0.54 & 0.6 & 0.48 & 0.54 & 0.6 \\
\hline$y$, depth of flow in bridge, ft & 9.01 & 9.75 & 6.96 & 9.01 & 9.75 & 6.96 \\
\hline \multicolumn{4}{|c|}{ Median stone Diameter for riprap at: left abutment } & right & abutment, & ft \\
\hline Fr< $<=0.8$ (vertical abut.) & 1.62 & 1.76 & 1.55 & 1.28 & 1.76 & 1.55 \\
\hline Fr>0.8 (vertical abut.) & ERR & ERR & ERR & ERR & ERR & ERR \\
\hline
\end{tabular}

